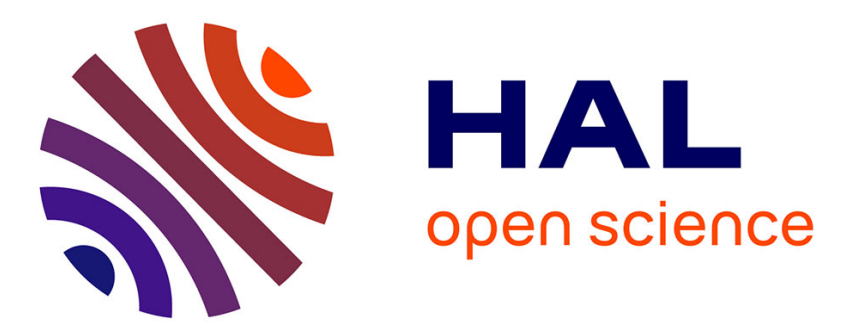

\title{
Market dynamism and international trade: a case study of Mediterranean agricultural products, 1850-1935
}

Vicente Pinilla, Maria-Isabel Ayuda

\section{To cite this version:}

Vicente Pinilla, Maria-Isabel Ayuda. Market dynamism and international trade: a case study of Mediterranean agricultural products, 1850-1935. Applied Economics, 2008, 40 (05), pp.583-595. 10.1080/00036840600707258 . hal-00581997

\section{HAL Id: hal-00581997 https://hal.science/hal-00581997}

Submitted on 1 Apr 2011

HAL is a multi-disciplinary open access archive for the deposit and dissemination of scientific research documents, whether they are published or not. The documents may come from teaching and research institutions in France or abroad, or from public or private research centers.
L'archive ouverte pluridisciplinaire HAL, est destinée au dépôt et à la diffusion de documents scientifiques de niveau recherche, publiés ou non, émanant des établissements d'enseignement et de recherche français ou étrangers, des laboratoires publics ou privés. 


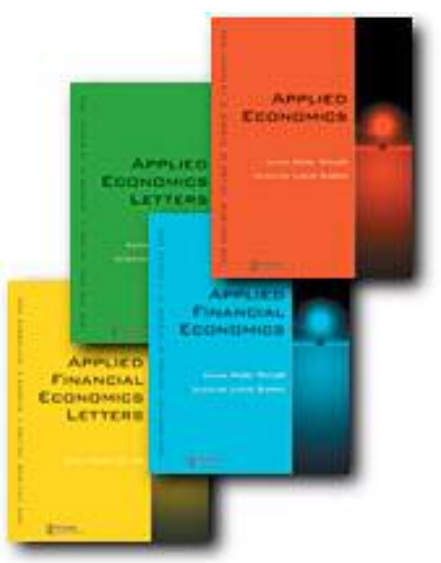

Market dynamism and international trade: a case study of Mediterranean agricultural products, 1850-1935

\begin{tabular}{|r|l|}
\hline Journal: & Applied Economics \\
\hline Manuscript ID: & APE-05-0535.R1 \\
\hline Journal Selection: & Applied Economics \\
\hline JEL Code: & $\begin{array}{l}\text { E21 - Consumption /Saving < E2 - Consumption, Saving, } \\
\text { Production, Employment, and Investment < E - Macroeconomics } \\
\text { and Monetary Economics, N30 - General, International, or } \\
\text { Comparative < N3 - Labor and Consumers, Demography, } \\
\text { Education, Income, and Wealth < N - Economic History }\end{array}$ \\
\hline Keywords: & consumption, agricultural products, international trade \\
\hline \multicolumn{2}{|l}{} \\
\hline
\end{tabular}

powered by ScholarOne

Manuscript Central ${ }^{\mathrm{H}}$ 
Market dynamism and international trade:

a case study of Mediterranean agricultural products, 1850-1935

\title{
VICENTE PINILLA and MARÍA-ISABEL AYUDA
}

- Vicente Pinilla: Department of Applied Economics and Economic History, University of Zaragoza. Gran Via 4 (50005) Zaragoza (Spain).

- María-Isabel Ayuda. Department of Economic Analysis. University of Zaragoza. Gran Via 4 (50005) Zaragoza (Spain).

Short title: Market dynamism and international trade

\begin{abstract}
:
This paper concentrates on analysing the rightward shifts of the demand curve for Mediterranean agricultural products from 1850 to 1938 . We have found that such shifts were especially conditioned by the different income elasticities of demand and by changes, or otherwise, in consumer preferences. Our aim is to show that there was an initial conditioning factor for the producer countries to take full advantage of these potential growth opportunities, namely the size of such shifts. The case of Spain serves to compare the effects derived from the evolution of the demand for two groups of products: Mediterranean horticultural products and wine.
\end{abstract}

- Address for correspondence: Vicente Pinilla. Department of Applied Economics and Economic History. Gran Vía 1-3 (50005) Zaragoza (Spain). Email:vpinilla@unizar.es. 


\section{Market dynamism and international trade: a case study of Mediterranean agricultural products, 1850-1935}

\section{Introduction}

The onset of the industrialisation process in a significant number of countries, above all in Western Europe, during the course of the nineteenth century gave rise to a whole series of economic effects. One of the most significant was the increase in the volume of international trade. This expansion was led by the process of globalisation and the associated price convergence (due to the sharp fall in transport costs and trade liberalisation) and by outward shifts in demand or supply curves (O'Rourke and Williamson, 2002).

In this context, the economic growth enjoyed by the more developed countries generated an increase in demand for products which they could either not produce themselves, or which could be obtained at lower prices on the international market. As a result, opportunities opened-up for the less developed countries to give momentum to their development through participation in international trade.

Focusing on Europe, considerable prominence has been given to the possibilities for the Southern European countries. At the same time, the responses of these countries to such possibilities and to the obstacles they had to face have attracted much interest. It has been suggested that globalisation not only opened up these opportunities but, by extending the production of traditionally Mediterranean products to other areas, could also have led to greater competition or to the establishment of trade barriers to protect nascent extra-European production (Federico, 1992; Morilla, Olmstead and Rhode, 1995; Pinilla and Ayuda, 2002; Ramon-Muñoz, 2000).

Against this background, this paper concentrates exclusively on analysing the rightward shifts of the demand curve for Mediterranean agricultural products. In this way, our aim is to show that there was an initial conditioning factor for the 
producer countries to take full advantage of these potential growth opportunities, namely the size of such shifts. This was a necessary but not sufficient condition for generating active international trade that was capable of driving the economic development of the Southern European countries. Logically enough, not all the products offered the same possibilities from the point of view of demand, and nor did they give rise to the same effects in the development process, in that the potential linkages conditioned the impact of the increase in trade on the economy as a whole.

In the specific case considered here, we shall compare the sizes of the demand curve shifts, and the reasons for them, for two products that had decisive weight in the agricultural economies and foreign trade of these countries, that is to say, wine and Mediterranean-type fruit and vegetables.

Our hypothesis is that both types of products exemplify very different growth possibilities that were made available by international trade. Thus, although by the time of World War II wine had still not become a mass consumer product beyond the borders of the traditional consumer countries (or populations of this origin), Mediterranean horticultural products had enjoyed a quite extraordinary diffusion outside their areas of production.

Logically enough, the evolution of international demand depended on a broad range of factors, associated with economic, social, cultural and other types of variables. In this paper, our objective is to concentrate exclusively on the relationship between the increase in per capita income and consumption, without in any way seeking to undervalue the impact that other factors may have had and, indeed, making reference to them ${ }^{1}$. In our view, the approach we have chosen allows us to isolate what was, in our judgement, a key variable in the evolution of demand. Such a viewpoint also has the advantage of permitting an econometric treatment of the available quantitative data, in such a way that we can establish with some precision the long-run relationship between both variables.

In order to meet our objective, the rest of the paper has been organised as follows. We first study the consumption of Mediterranean horticultural products

1 An extensive international literature supports our choice of this option: see, for example (Chaudhri and Timmer, 1986). 
and the evolution thereof, before transferring this analysis to the case of wine. We then consider the impact of the evolution in international demand on Spain, a large-scale producer country. The paper closes with a review of the main conclusions.

\section{Fruit and vegetables: a dynamic market}

A key element in the globalisation of the production and trade in Mediterranean horticultural products is represented by the very marked increase in their consumption. Although such goods were initially consumed by very limited sections of the population in the countries of north-western Europe, the increase in supply in response to the excellent possibilities and profits coming from their trade, and the increase in incomes enjoyed by the population of these countries in the second half of the nineteenth century, opened the possibility of their consumption to the ever-increasing middle class and, subsequently, to the working class. Thus, what were once considered exotic products became habitual elements in the diets of the peoples of northern Europe and North America. Obviously, the increase in the populations of these industrialised countries between 1850 and 1938 also contributed to the increase in demand.

In the epochs before the onset of the various industrialisation processes, contrasts in the composition of the diets consumed by the populations of the different European countries were basically defined by their endowments of natural resources, given that long-distance trade in foodstuffs was very limited. As is well known, this was linked essentially to the firmly established trade in cereals, albeit in limited amounts as compared to those traded subsequently.

The improved possibilities for the cultivation of fruit and horticultural products in the countries of southern Europe increased their importance in the diet consumed by their populations.

Differences in terms of calories consumed by the inhabitants of the diverse areas of Europe were probably not significant prior to industrialisation (Yates, 1960). However, the marked increase in the per capita income of the countries most involved in the industrialisation process meant that the diets of the European peoples, especially those of western and northern Europe, began to change. The 
first of these changes took the form of an increase in their consumption of calories. This initially came from the most habitual foodstuffs. Subsequently, it resulted from the diversification of the diet of these populations groups, who began to consume products that were already available from their respective areas but to which they had traditionally, and for economic reasons, enjoyed either very limited access, or none at all. Finally, there was an increase in the consumption of commodities whose production was either very limited in these areas or simply not viable from the ecological or economic point of view.

Once acceptable levels of consumption had been assured, this diversification of diet led to a fall in the consumption of traditional foodstuffs, such as those derived from cereals and potatoes. By contrast, meat and livestock products in general, together with oils and fats, sugar, fruit and vegetables and beverages derived from cocoa, coffee or tea, were the commodities that benefited most from this diversification.

Consumption of fruit and vegetables in the industrialised countries tended to increase from levels that were relatively very low. This was especially the case with respect to fruit, the consumption of which generally grew much more rapidly than that of fresh vegetables. Despite this strong growth, and once high levels of development had been reached, the part represented by the consumption of fruit and vegetables in the total calories consumed was considerably higher in the countries of southern Europe, which still had very low levels of development, than in those of north and central Europe, where diets had already achieved levels appropriate to developed countries ${ }^{2}$. This reveals the persistence of significant differences in the types of diets despite the dietary changes that had come about as a consequence of the increase in the income levels of the developed countries. These differences were linked essentially to the respective national traditions. In general, they are a reflection of the fact that the populations of each country

\footnotetext{
${ }^{2}$ According to Yates (1960), utilising FAO data for 1957, in the three types of ideal diet that he identified, namely that of north, central and southern Europe, fruit and vegetables represented $5.2 \%, 6.3 \%$ and $11.8 \%$, respectively, of the total consumption of calories. The central diet was $6.8 \%$ lower than the northern diet in terms of calories consumed, whilst the southern diet was $17.5 \%$ lower than the northern and $11.5 \%$ lower than the central diets.
} 
tended to consume more of the foodstuffs actually produced there, and that dietary diversification might mean changes in function of what was the previous pattern of consumption. That is to say, an increase in income tended to translate into an increase in the amounts of the products that had traditionally been consumed to a lesser extent.

The analysis of the foreign trade statistics of the United Kingdom, the main importer of these products throughout the period under analysis, with respect to a group of very representative commodities from amongst those being considered, clearly demonstrates the rapid increase that took place in imports of fruit and vegetables coming from a Mediterranean origin. Given that the United Kingdom's production of these foodstuffs was either very small or nil, these import data represent an excellent approximation to the variation in their consumption.

INSERT TABLE 1.

Table 1 shows that the rate of increase in imports of some of the most representative horticultural products from the Mediterranean was extremely high. This rate was in fact much higher in the second half of the nineteenth century than the first third of the twentieth, which is perfectly understandable if we bear in mind that the starting levels were very low. In absolute terms, the increase in imports was truly impressive.

From Table 1 we can also appreciate that the increase in imports due to the rise in per capita consumption was much more important than the simple increase in the population. This strong increase in imports per inhabitant is a clear reflection of the growth in per capita consumption of fruit and vegetables on the part of the population of the United Kingdom. Drawing on data from the twentieth century (given that we lack data for earlier periods), we find that whilst spending on foodstuffs, at constant prices, rose by some 12.3 per cent between 1900 and 1935 , spending on fruit and nuts increased by no less than 62.3 per cent and on vegetables by 47.3 per cent during the same period (Stone, 1954).

We may draw the conclusion that in the long-term the increase in the consumption of fruit significantly exceeded that of foodstuffs as a whole. Even so, the per capita consumption of fresh fruit in the United Kingdom during the years prior to the Second World War was only 62.4 per cent of the Australian level and 
57.6 per cent per cent of that of the United States (1934-8 for the United Kingdom and 1935-9 for the United States)( Commonwealth Economic Committee, 1957).

Turning to United States data, we again find a significant increase in the consumption of fruit and vegetables and, above all, of certain processed products, such as preserves or juices, during the first third of the twentieth century. The increases that Fox calculates for a number of specific products between 1909 and 1950 are also spectacular. Thus, the per capita consumption of table grapes had multiplied by nine, that of fruit preserves by seven, and that of fruit juices by twenty nine. By contrast, during the same period the consumption of wheat flour had fallen by 33 per cent, that of corn flour by 70 per cent and that of potatoes by 50 per cent(Fox, 1953) ${ }^{3}$. Thus, during the years prior to the Second World War the United States had the highest per capita consumption of these types of products of all the industrialised countries (Hollingshead and Wakefield, 1929). If we further take into account the significant growth in the population of the United States, it is clear that this country was the main international consumer of Mediterranean horticultural products.

The cases of the United Kingdom and the United States are very representative of what occurred in the developed countries. OEEC studies have concluded that between 1913 and 1957 the rate of growth in the annual per capita consumption of fruit significantly exceeded that of any other type of foodstuffs, whilst vegetables, although not enjoying such dynamic performance, also occupied a relatively good position (Yates, 1960).

\section{Increase in income and growth in consumption}

The explanation for the strong growth in the per capita consumption of Mediterranean horticultural products lies above all, although not exclusively, in the fact that such consumption responded comparatively well to changes in income. The relatively high income elasticity of demand of these products as compared to other foodstuffs was, therefore, a key element in this growth.

\footnotetext{
${ }^{3}$ Shultz (1953) has also verified that between 1909 and 1949 the products which enjoyed the greatest increase in per capita consumption were citrus fruits and tomatoes $(+54 \%)$.
} 
Other factors that also acted as a motor for this increase in consumption were the publicity campaigns launched by the fruit distributors in countries such as the United Kingdom, France and the United States ${ }^{4}$. These campaigns, which were only relevant from 1920 onwards, frequently highlighted scientific discoveries that placed emphasis on the significant contribution of vitamins or minerals offered by these products and, therefore, their importance for nutrition and health. To that end, they used members of the medical profession and scientists to act as "credible" broadcasters of such discoveries (FAO, 1948). Particularly interesting were the efforts made by Californian producers to promote the consumption of citrus fruits using a variety of innovative ideas, such as spreading the popularity of fruit juice squeezers, at first, manual, and later, electric-powered, or using wrapping paper for oranges that contained recipes for the inclusion of these products in more elaborate dishes.

Furthermore, the urbanisation process and the decline in the need for "strong" foodstuffs with the arrival of a pattern of life that demanded less physical effort, also favoured the growth in the consumption of these products ${ }^{5}$. In summary, changes in working and living conditions encouraged suitable nourishment of a less heavy kind (Ritter and Guttfeld, 1932). Whilst this wide range of causes, all of them linked to industrialisation and economic development, acted as a motor for such consumption, there is no doubt that one of the main consequences of this development, the increase in per capita income, played an absolutely determining role.

Fruit was initially a luxury product, with consumption tending to increase above all for the high income population group. At the end of the nineteenth century, it was still to some extent regarded as a luxury good in the United

${ }^{4}$ Liniger (1962) for France; Moriarty (1930) for the United Kingdom; Faugeras (1931) for the United States. The emergence of modern nutritional science in the second part of the nineteenth century played an important role in shaping dietary changes in industrialised countries. In the case of fruits, the importance of vitamins began to be understood in the period between the 1880s and World War I. See Offer (1991).

5 This theme has been analysed for a period immediately prior to the one considered here by Clark, Huberman and Lindert (1995). 
Kingdom, France and Germany and, although desired by the population as a whole, lower income population groups continued to have only limited access to such products (Department. of Commerce, 1904; Liniger, 1962).

Highlighting the sharp differences in this regard between the different social groups, the available data on food consumption and diet for the United Kingdom, show how low incomes dramatically limited choice (Burnett, 1989; Oddy, 1976). In the face of the uncertain dietary and food situation affecting a significant part of working class families, fruit and vegetables were normally an unattainable option. Thus, there were frequently differences of as much as ten times in spending on fruits between the highest and the lowest income groups (Nelson, 1993). The fruit consumed by the working class consisted essentially of currants (habitually used for making "roly-poly") and jam. The fall in the prices of bread and meat as a consequence of the sharp increase in imports from the New World and Australia left a significant part of income available for the purchase of other foodstuffs, from amongst which fruit and vegetables, together with eggs and dairy products, benefited the most. In the case of the United Kingdom, it is interesting to note that by the middle of the 1930 s fruit was one of the foodstuffs with the steepest gradient of consumption in terms of income, with consumption being eight times higher in the highest income decile than in the lowest (Neumark, 1991). During this same period, 1936-7, the study made by Sir William Crawford also confirmed the dramatic differences in the consumption of fruit, above all in the two extreme classes of the five into which the population was divided on the basis of their incomes. Notably, there was a clear convergence between the first three of these classes (25 per cent of the population), who enjoyed a very widespread consumption of fruit, and the last two ( 75 per cent of the population) in which fruit was consumed in only a very small number of families (Burnett, 1989). In the United States, by 1942 the differences between income groups in the consumption of these products were considerably smaller, at least in urban homes (Ojala, 1952).

The well-known work of Stone concluded that the income elasticity of these products was relatively high when considered as foodstuffs. Thus, using United 
Kingdom budgetary surveys for 1936-7 and 1937-8, he calculated a value of 1.34 for fruit and 0.86 for vegetables, as compared to 0.53 for foodstuffs as a whole ${ }^{6}$.

The income elasticities of demand for the same period, 1913-1958, and for the OECD countries, again show the highest value for fruits, 1.97, and a much more moderate one for vegetables, 0.54 (Yates, 1960).

Though they reflect values that were high in the context of foodstuffs, the elasticities reported in these works unfortunately refer to years subsequent to those considered in this paper. By this time in fact, the consumption of Mediterranean horticultural products enjoyed wide-spread popularity among the populations of the industrialised countries.

In our case, we propose to extend the analysis of the relationship between income and the consumption of these types of products to the totality of the period under analysis, that is to say, to the years $1850-935$. To that end, and as the most representative product of Mediterranean fruit and horticultural production, we have chosen the case of the consumption of oranges in the United Kingdom, which reflects a number of characteristics that justify our choice. First, the United Kingdom did not produce oranges, which means that we can approximate its imports to national consumption. Furthermore, prior to the outbreak of the Second World War, oranges and apples were by far the most commonly consumed fruits, with annual consumption exceeding 20 pounds per person, while no other fruit normally reached 5 pounds, save bananas which ranged between 10 and 15 pounds (Neumark, 1938). The results that we obtain will hopefully be of use in a number of areas. First, to validate those obtained in studies cited earlier. Secondly, and given the length of the period covered, they will allow us to better understand the long-term relationships between the consumption of these products and income, not only for the United Kingdom but also for other countries that were undergoing the industrialisation process. Finally, we should recall that all previous

\footnotetext{
${ }^{6}$ Stone (1954). The income elasticities of demand of the individual products were as follows: various fresh fruits and nuts (1.62), tinned and bottled fruit (1.34), apples (1.33), bananas (0.95), oranges (0.92), fresh vegetables and pulses (0.93), tubers (excluding potatoes) and tomatoes (0.85), dried fruits (0.75), tinned and bottled vegetables (0.70) and onions (0.22).
} 
studies of this type have been carried out either for the inter-war years or for those following the Second World War, that is to say, times when the level of development of the industrialised countries could be considered as high.

Thus, for the period 1854-935 we propose a model in which the dependent variable is the per capita consumption of oranges $\left(\mathrm{CO}_{\mathrm{t}}\right)$, with the independent variables being income per capita $\left(\mathrm{I}_{\mathrm{t}}\right)$, the price of oranges $\left(\mathrm{PO}_{\mathrm{t}}\right)$ and the price of raisins $\left(\mathrm{PR}_{\mathrm{t}}\right)$. As a consequence, we are assuming that the consumption of oranges is determined by the evolution of per capita income, by their price and by the price of their main substitute product ${ }^{7}$. In the models all the variables are in natural logarithms. We also introduce two dummy variables, $\mathrm{D} 1_{\mathrm{t}}$ and $\mathrm{D} 2 \mathrm{t}_{\mathrm{t}}$. The first, $\mathrm{D} 1_{\mathrm{t}}$, seeks to reflect the particular situation of the years covering the First World War and the immediate post-war years, where we assume that first the war itself, later the submarine blockade and finally the post-war era all represent a somewhat anomalous situation. The second, D2 $2_{t}$, seeks to determine whether some differences existed between the consumption elasticities before and after 1896, given that the Chow test indicates a structural change.

In the econometric analysis, we first studied the individual behaviour of the three series by using the graphics, the correlograms and certain tests as the Dickey-Fuller test (Dickey and Fuller, 1979, 1981). The unit root tests show that all variables in level form have a unit root. Using the method suggested by EngleGranger and Johansen we consider that the variables are cointegrated (Engle and Granger, 1987). Hence the error correction form is an appropriate model.

The error correction model can be estimated either by the maximumlikelihood estimation of the short-run and long-run parameters, or by using the two-step method suggested by Engle-Granger (Engle and Granger, 1987). The two-step method first estimates the long-run parameters as the equilibrium relationship in level form. The estimate of the residual vector thus obtained is then used in the second step estimation of the error correction mechanism and, thus, we

\footnotetext{
${ }^{7}$ For the inter-war years, Stone introduced dried fruits, bananas and fresh vegetables as substitute products. Although the substitution elasticities obtained were all positive, dried fruits being the highest, none of them were significant in the final analysis. Stone (1954).
} 
obtain the short-run parameters. In this study we use the first method and estimate all parameters simultaneously, with this approach yielding efficient parameter estimates (Johansen, 1991). The results are presented in Table 2.

\section{INSERT TABLE 2}

After estimating different models, we have chosen that which appears in Table 2, given that all the variables in the model are significant at 5 per cent save for the orange and raisins price variables in the short-run and the raisins price variable in the long-run. The chosen model does not exhibit either heterocedasticity or autocorrelation problems and, furthermore, has the smallest value of the AIC (Akaike Information Criterion) and SBIC (Schwartz Bayesian Information Criterion), and the biggest value of the adjusted $\mathrm{R}^{2}$.

The most noteworthy results of this analysis are the very high income elasticities obtained for the second half of the nineteenth century (3.05), whilst those corresponding to the first third of the twentieth, although lower, are nevertheless significantly higher than those obtained in the studies cited earlier for a similar or very proximate period of time (1.99). Thus, during the second half of the nineteenth century, decades that we might consider as reflecting the dramatic spread of these types of products in the markets of the industrialised countries, increases in income translated into much sharper increases in demand. Furthermore, the lower levels of income present in the first period also help to explain the greater elasticity it reflects. This result is in line with that forecast by Engel in 1888 when he formulated his well-known law, and verified subsequently by authors such as Clark or Shultz when further extending this line of research (Clark, 1957; Shultz, 1953).

The high elasticity of fruit corresponding to the industrialisation phase of the European countries would appear to confirm, as indeed some pioneering works had already suggested, that there could have been a 'hierarchy' of food categories on the basis of costs per calorie: thus, 'as incomes increase, people would move down the hierarchy, their food budget share of preferred (i.e., costlier) foods would rise with increasing incomes' (Chaudhri and Timmer, 1986). 
Bennett established a calorie-price hierarchy made-up of eight groups, with fruit and vegetables appearing at its head (Bennet, 1957) ${ }^{8}$.

In the light of the above, it is easy to appreciate the opportunities that had been opened to producers in these markets. As a result, agricultural specialisation in this direction was an option available to the countries of the Mediterranean periphery of Europe as a means to take full advantage of the potential offered to them by international trade.

The surprising sign of the price elasticity (unless our price data suffers from problems) can, we believe, be explained by the evolution of the price and consumption series. Whilst the increase in consumption coincided with a significant fall in prices until some years prior to the end of the nineteenth century, the subsequent relationship between both is more complex. The new falls in prices that took place immediately following this period coincided with a standstill in consumption, whilst during the First World War the relationship is as expected (high prices implying a fall in consumption) and, thereafter, increases in prices took place simultaneously with a sharp increase in consumption. It could be argued that if, this fall in prices might have favoured the extension of consumption up to the last decade of the nineteenth century, from this time onwards the consumption of oranges by families that had adopted this product as part of their habitual diet was not influenced by prices. Indeed, even at times of price increases, consumption itself increased. In explaining the price inelasticity of consumption of oranges, it should be remembered that they are a difficult product to substitute. Not only did consumers identify them as a clearly different product from the rest, but in the winter season the range of alternative fruits was limited.

\section{The evolution of wine consumption: divergent patterns}

\footnotetext{
${ }^{8}$ The universal character of this hierarchy has been questioned. However, in 1975, and for countries with very different levels of development fruit and vegetables were again habitually placed at the head of this hierarchy. See Chaudhri and Timmer (1986).
} 
Wine has been a traditional product of the Mediterranean basin. Within this part of the world, Portugal, Spain, France and Italy in particular were the main producers and consumers. The cultural tradition of wine consumption in this region is linked to the presence of the appropriate climatic conditions for its development. However, the international trade in wine, of which we have knowledge dating from at least Greco-Roman times, made possible its diffusion into other areas of Europe.

In spite of this trade, in the last quarter of the nineteenth century wine was the predominant alcoholic beverage only in the countries of Southern Europe. In Northern and Central Europe, beer and spirits prevailed. In countries with populations of European descent, the patterns of consumption of the countries of origin were usually repeated. For example wine prevailed in Argentina, but beer was the predominant beverage in the United States and Canada. Differences in national preferences have been explained on the basis of economic factors, such as the availability of the product, poor market integration, relative prices, etc, and/or based on cultural or anthropological factors, such as tradition, religion, fashion, etc.

Interestingly, the increase in wine consumption between 1850 and 1938 chiefly took place in the traditional wine-consuming countries, whilst the initial increase in wine consumption in the countries of Northern and Central Europe stopped towards the last quarter of the $19^{\text {th }}$ century at relatively very low levels ${ }^{9}$.

Consequently, we can conclude that only in a small corner of the world, namely the countries abutting the north-western shore of the Mediterranean, was wine considered to be a product of mass consumption. This was the case in Portugal, Spain, France, Italy and French and Italian speaking Switzerland, where per capita average annual wine consumption was above 50 litres. Only in a few other countries, such as Argentina, Uruguay, Chile, southern Brazil and Greece was wine consumption of any significance. In the rest of the world, if wine was consumed at all, it was consumed by the high-income classes.

9 Pan-Montojo (1994) confirms that between 1840 and 1870 there was a doubling of the per capita consumption of wine in the UK, Belgium, the Netherlands and the Scandinavian countries. 


\section{INSERT TABLE 3}

The case of the United Kingdom represents an excellent example of what occurred in those countries where wine had not become a mass consumption product. Using import data for the United Kingdom, we can verify that between 1855 and approximately 1875, wine imports increased sharply, more than doubling over the period (Briggs, 1985; Nye, 1991). This increase could be connected with the tariff reduction on French wines in 1860, following the trade agreement between France and the United Kingdom. In addition, there were further tariff reductions in 1861 and 1862. The expansion in wine consumption did not imply a decline in the consumption of beer or spirits. On the contrary, this decline it happened at the same time, although faster in the case of the latter. From 1875 until the beginning of the twentieth century, beer and spirit consumption remained relatively high, before suffering a sharp decline (see Figure 1).

INSERT FIGURE 1

Why did the growth in British wine imports halt after 1875, even though they were still small in relation to its population? The answer lies in the fact that until the Second World War and for some decades thereafter, wine consumption in Great Britain was restricted to a small segment of the population which enjoyed high per capita income. Thus, wine was never a real alternative to the traditional consumption of beer for the majority of the middle and lower classes ${ }^{10}$. It is similarly significant that British preferences focused on fortified wines, such as sherry and port, and sparkling wines, such as champagne, while table wines had less prominence. Among the table wines, the most important were the clarets from Bordeaux. These were in general wines of both high quality and price, which made their diffusion more difficult. The price differences between the types of wine most commonly consumed in the United Kingdom and ordinary table wine were particularly marked with sherry, for example, costing up to ten times more per litre than ordinary table wine (Simpson, 1995).

${ }^{10}$ Briggs (1991) quotes Leoni who calculated that in 1880 the working classes consumed $75 \%$ of all beer and spirits consumed in the country, but only $10 \%$ of the wine. 
The available data on per capita consumption in Great Britain is similarly conclusive. Between 1870 and 1938, wine expenditure in the United Kingdom ranged from between 5 and 10 per cent of the total expenditure on alcoholic beverages, decreasing with the passage of time (Prest, 1954; Stone, 1954). Per capita consumption also declined in the same period, and likewise consumption of all other alcoholic beverages during the first third of the twentieth century. The main reasons why wine consumption did not expand in Great Britain during the period were the absence of any tradition of wine consumption, unawareness of the product and its high price in comparison to beer ${ }^{11}$. According to Simpson, the difficulties in establishing objective measurements of quality by way of which consumers could evaluate the different wines, together with the significant variations in that quality and the frequent adulteration of the product, also made its diffusion more difficult in the British market (Simpson, 2004).

The French case is particularly illustrative of the opposite trend. France was the country with the highest per capita consumption in the world. The study of the French case will help us to understand what happened in countries in which wine had a similar importance in terms of consumption.

During the "Ancien Regime", wine consumption in France was low among the popular classes and high among aristocrats, the clergy and the bourgeoisie. Low per capita income and a high relative price were the main obstacles to the increase in wine consumption. High transport costs and poor market integration generated very different regional consumption patterns and much higher levels of per capita alcohol consumption in producing regions. From approximately the middle of the $19^{\text {th }}$ century and until the 1920 's, two trends emerged with respect to wine consumption in France. First, per capita consumption grew substantially and secondly, some degree of convergence in consumption patterns took place between north and south, rural and urban areas and different social classes (Sournia, 1990).

\footnotetext{
${ }^{11}$ Briggs (1985) and Nye (1991) noted that the British preference for beer and gin consumption over wine must also be linked to the discriminatory British trade policy established in 1670, which continued for almost two centuries.
} 


\section{Explaining the growth of wine consumption}

It is significant that the per capita wine consumption in France more than doubled between 1860 and the years prior to the First World War. After a slight decrease, as a consequence of the war, consumption levels almost recovered their pre-war levels, although these were never exceeded.

Our hypothesis to explain the evolution of wine consumption in France is that the strong increase in per capita income was translated into an increase in wine consumption. The growth in per capita income was the result of the economic changes brought about by the industrialisation of the country. The construction of the railroad network resulted in better communications, which allowed greater accessibility to products from distant regions at low prices. The increased commercialisation of wine over long distances was also facilitated by improvements in the techniques for producing and preserving wine ${ }^{12}$.

To analyse this hypothesis we have used aggregate time series to estimate the short-run and long-run responsiveness of per capita wine consumption (W) to the wine price $(\mathrm{P})$ and to French per capita real income (I). That is, we are assuming that per capita wine consumption is determined by the evolution of French per capita income and by its price. In the models all the variables are in natural logarithms. We have used data for the years 1860-913, 1920-38. Data from 1914 to 1919 are not reliable because of the First World War. We also introduce a dummy variable (D), which seeks to determine whether any differences exist between elasticities before and after the First World War.

As in the case of oranges, the econometric analysis first considers the individual behaviour of the three series by using the graphics, correlograms and also certain tests, such as the Dickey-Fuller (Dickey and Fuller, 1979, 1981). The unit root tests show that all variables in level form have a unit root. Using the method suggested by Engle-Granger and Johansen, we may establish that the variables are cointegrated (Engle and Granger, 1987; Johansen, 1991). As in the previous case, we have used the error correction model. Using the maximum-

\footnotetext{
${ }^{12}$ It should be remembered that Louis Pasteur's important research on the production and preservation of wine was published in 1866 .
} 
likelihood estimation of the short-run and long-run parameters, the results obtained are presented in Table 4.

\section{INSERT TABLE 4}

After estimating various different models, we have chosen the one given in Table 4, because it exhibits the smallest value for the AIC (Akaike Information Criterion) and SBIC (Schwartz Bayesian Information Criterion), and the biggest value for the adjusted $\mathrm{R}^{2}$.

On the basis of this econometric analysis we may conclude that the increase in real income enjoyed by the French population explains, in part, the strong growth in wine consumption in France from about the middle of the nineteenth century up to the Second World War. This means that the population translated the long-run income increase into a higher demand for wine. The short-run income variations also affected consumption, but not to the same extent. In the inter War period, we may note a limited response of consumption to variations in per capita income. This may be interpreted as the French having incorporated wine consumption into their everyday diets, and not substantially modifying this practice in the face of small variations in their income. The comparison between the estimated elasticities of wine and oranges, respectively, in France and the United Kingdom is significant. The differences are important and point to very distinct rhythms in the evolution of their demand. This is particularly so if because in the case of wine we have chosen a country in which consumption grew significantly, but which, at the same time, is hardly representative of the more industrialised countries. Finally, the incidence of long-run price variations over wine consumption, whilst significant, is not particularly large. This may be interpreted as showing that the French people had come to consider wine as an everyday consumption good.

Accordingly, we can conclude that wine consumption grew mainly in those countries in which it had traditionally been drunk. We have verified, using the French case, how the increase in wine consumption in those countries was mostly determined by growth in per capita income. In the rest of the world, wine consumption grew in those countries that received immigrants from Southern Europe. Everywhere else, the increase in wine consumption was either not large, or simply did not occur. In the industrialised countries (excluding France), with 
higher per capita incomes, the increase in consumption was significant, especially in the decades after 1850, although later the trend did not continue. The attractive prospects from the demand side that existed in the second half of the nineteenth century tended to evaporate in the first third of the twentieth century. In some developed countries, the rapid development of wine imports, which were a consequence of the general increase in international trade, slowed down as imports encountered the difficulties noted earlier.

\section{Agricultural exports and economic development in Spain}

In this paper we have tried to highlight how the increase in international trade that took place from the middle of the $19^{\text {th }}$ century until the onset of the economic crisis in 1929 translated into increases in the trade in primary products that differed very considerably from product to product. Thus, if we compare the period 1909-13 with that of 1928-32, we may note that whilst the total trade in these type of products grew in volume by some 38.9 per cent, the trade in wine increased by only 20.2 per cent, whilst trade in fruit achieved an increase of no less than 79.7 per cent. Perhaps even more significantly, the trade in fruits during the period 1928-32/1934-38 actually grew by a significant 4.8 per cent (Aparicio, 2000), despite the fall in the total trade in foodstuffs and agricultural products such as wine from 1929 onwards., During the second half of the nineteenth century, the trend followed by both products had been similarly diverse. On the one hand, there was a dramatic increase in the trade in wine, above all as a consequence of the demand coming from France during the phylloxera outbreak, only for this to fall sharply in the last decade of that century (Pinilla and Ayuda, 2002). By contrast, the trade in fruit enjoyed a sustained pattern of growth throughout this period.

We have tried to demonstrate that such diverse trends were decisively influenced by the response of consumption to the rise in income that took place in the more developed countries. Clearly, the evolution of trade was not conditioned solely by the evolution of consumption. This evolution opened a broad range of possibilities, with trade policies, the increase in international competition and the 
response of the different suppliers determining the final position of the producer countries in the different markets.

The case of Spain is particularly significant, in that the two types of products considered in this paper occupied leading positions, at least in terms of export volumes, in that country. By way of illustration, Spain was the leading world exporter of wine throughout the first third of the twentieth century and for the majority of the second half of the nineteenth, if we exclude the case of post1900 Algeria, whose exports entered the French market duty free, and which we may consider as domestic rather than international trade. It was also the leading world exporter of oranges, almonds and fresh table grapes.

\section{INSERT TABLE 5}

Although there were other factors that exerted a marked influence on Spanish export possibilities, the evolution of consumption established a number of decisive limits. The discriminatory policies applied by France in favour of wine from its own colonies, or those implemented by the United States to support its growing fruit sector affected the main markets for both types of Spanish products, and this conditioned and influenced the development of Spanish exports, as did the increase in the production of wine and Mediterranean horticultural products in the new producer countries. However, at the end of the day it was the evolution of per capita consumption which acted as the decisive limiting factor on export possibilities and contributed emphatically to explaining their results.

\section{INSERT FIGURE 2}

If we compare the importance of both types of products in Spanish foreign trade, we find that their trajectories are clearly different. Initially, they both had relatively similar weight in this trade, of between 5 per cent and 10 per cent of total exports, and the initial impulse they enjoyed was also similar. However, these trajectories were not long in beginning to diverge. Thus, wine began to enjoy a dramatic rate of growth, above all on the back of the demand generated in France as a result of the phylloxera outbreak, until it had attained some 40 per cent of total Spanish exports by 1890 . The collapse associated with the fall in this demand, which itself was a consequence of the recovery of the French vineyards and the increasing importance of imports from Algeria, which entered duty free, 
represented an extremely strong contraction of export volumes which, throughout the first third of the twentieth century, brought wine down to levels similar to those from which it had originally started. In this way, Spain's highly competitive wine production could not compensate for the low level of consumption of this product outside the traditional consuming countries.

By contrast, the relative importance of Mediterranean horticultural products within total exports only became apparent following the decline of wine exports. These products began to exhibit an increasing trend from the beginning of the twentieth century, with only a temporary interruption during World War I, in such a way that by the mid-1930s they represented some 40 per cent of total Spanish exports.

\section{INSERT FIGURE 3}

It is obvious that both trends were determined not only by their own evolution and that of their prices, but also by total exports. If we concentrate exclusively on the export volumes viewed through the volume index that we have constructed, then we can appreciate with greater clarity what took place. The exports of Mediterranean horticultural and fruit products passed through a phase of uninterrupted expansion (with the exception of World War I)- from 1850 to 1935, with export volumes multiplying by more than 11 times during this period. By contrast, the trend followed by wine was very different. Exports similarly began a phase of prodigious growth that by 1890 had already recorded an almost identical rate, that is to say, multiplying its volume by no less than 12 times. However, it subsequently suffered a very rapid collapse and continuous instability throughout the first third of the twentieth century. Such an irregular trend was influenced by the market to which a substantial part of Spanish exports were directed, namely France. At the same time, the markets of the industrialised countries that were not wine producers, or which produced only a small volume, and in which Spain benefited from a solid position, never had a significant absorption capacity as a consequence of their low consumption of wine.

From the point of view of the economic development of Spain, the consequences of two such very different trends were clearly important. Thus, although both types of exports made a significant contribution to this development 
through the foreign currency that was made available to finance necessary imports, they nevertheless fulfilled very different roles in the momentum given to agricultural and agri-industrial development.

Wine was very important during the export boom period in that, without the need to implement significant technological change, and simply by extending the area of vineyards under cultivation, it was possible to respond very rapidly to the demand coming from France and other countries. The increase in exports and a prevailing economic climate of clearly increasing prices gave rise to significant income for the producers. However, given the existence of demand for a type of product characterised by its high alcohol content and strong colour, but limited production process, no impulse was given to the technological development of the sector that might have positioned Spanish wine in the more favourable situation of the high quality sector. The arrival of the phylloxera blight, the discriminatory tariff policy applied by France in favour of Algerian imports and the commercial obstacles faced by Spanish wine in other countries such as Argentina and Uruguay, implied the coincidence of very variable and sharply declining demand with the need to make important capital investments to replant the phylloxeradamaged vineyards. As a result, throughout the first third of the twentieth century, the Spanish wine producing sector was faced with frequent surpluses, irregular and falling prices and, in general, serious difficulties.

If we turn now to the case of Mediterranean horticulture, we find a very different set of circumstances in that, whilst the response to increasing international demand made it necessary to introduce significant technological changes, the solid and permanently increasing trend followed by demand represented a permanent impetus to production which led to important benefits for the areas that were more specialised in agricultural exports (Palafox, 1983; Pinilla and Ayuda, 2003).

The paths followed by both trends are brought even more clearly into focus if we consider the opposite directions taken by the evolution of these products within Spanish agricultural production as a whole. Thus, wine production, which represented 15.7 per cent of total agricultural production in 1891, had fallen to just 7.9 per cent by 1931. By contrast, fruit production, which at the first of these dates represented only 5.2 per cent of total production, had 
increased to 10.4 per cent by the second (Grupo de Estudios de Historia Rural, $1987)^{13}$.

\section{Concluding remarks}

International trade opened up significant opportunities for the less developed countries of the European periphery which could by participating acquire momentum for their economic development. In this paper, we have sought to stress the fact that for Spain, despite the enormous capacity of its agri-industrial sector to react speedily in response to market signals, these opportunities were very diverse, and depended on a range of other variables. In this regard, we have concentrated on analysing variations in the size of the shifts in the demand curve and the reasons which lay behind them. We have found that such shifts were especially conditioned by the different income elasticities of demand and by changes, or otherwise, in consumer preferences. As a consequence, whilst the evolution of consumption, in some cases generated by profound changes in diet, was particularly varied in nature, in the cases of fresh fruit and vegetables, where this demand was high, it offered important opportunities to which the supply side had to offer a response. The lengthy period during which consumption enjoyed sustained growth has been illustrated with the estimations of the demand function for oranges in the United Kingdom, in this way highlighting the importance of the evolution of income in that growth.

By contrast, the case of wine has clearly shown that the possibilities which had been opened up were not in fact exploited, which was a consequence of the limited changes in traditional consumption patterns for alcoholic drinks. The fact that, despite the increase in income in the countries forming the nucleus of European industrialisation, there was no increase in the demand for wine beyond the countries lying on the northern shore of the Mediterranean, or in those that had received significant immigrant flows from that source, meant that the potential

\footnotetext{
${ }^{13}$ This calculation has been made at 1910 prices. The trend described is maintained using current values. Whilst wine saw its importance declined by half between 1891 and 1931, that of fruit and vegetables doubled (Grupo de Estudios de Historia Rural, 1983).
} 
opportunities were not in practice developed. These opportunities have been examined in detail for the case of France, where the increase in income was indeed translated into an increase in demand, albeit with a considerably lower elasticity.

Although in this paper we have not considered other alternative factors, it is our view that the consumption of the products analysed here could also have been influenced by the attitude taken to them by the science of Medicine and by modern dietetics, particularly since the beginning of the twentieth century. In the case of fruits, the widespread view in favour of an increase in their consumption taken by experts in these fields in the developed countries could have acted in their favour. Wine, by contrast, came up against precisely the opposite situation, because of the limitations on consumption recommended by the healthcare community and the temperance movements, which were particularly relevant in the English-speaking countries.

As a result, whilst the growth in production and exports of Mediterranean horticultural products was important for the development of the Spanish exporting regions, and made a significant contribution to their economic development, the role played by the increase in the production and export of wine was much more episodic and based on prevailing circumstances, being concentrated essentially in the years in which the phylloxera outbreak devastated the French sector. A different trade policy on the part of France might have meant a greater increase in Spanish exports, but this would have done no more than highlight the point to which Spanish exports depended on the consumption of those countries whose populations had traditionally consumed this drink.

\section{ACKNOWLEDGEMENTS}

We are particularly indebted to Antonio Aznar, Domingo Gallego, Peter H. Lindert, Alan L. Olmstead and the Institute for Governmental Affairs of the University of California, Davis. Previous versions have been read and commented on by the participants at the Economic History Seminar at the University of Zaragoza (1997 and 2003), the $6^{\text {th }}$ Spanish Economic History Congress (1997) and the $5^{\text {th }}$ European Historical Economics Society meeting (2003), as well as by 
Chris Lloyd, Jacob Metzer and Cormac O'Grada. We have relied upon finance from the Spanish Department of Education, Projects PB 98-1596 and PB 98-1579 and the Spanish Department of Science and Technology, Project BEC 200203789 .

APPENDIX: Data explanations and sources

A) Table 2. Oranges consumption function: United Kingdom (1854-1935).

GDP: GDP at constant prices (1900 prices), Mitchell (1988).

Orange imports: Statistical Abstract. Until 1892 the statistics drew no distinction between the amounts of oranges and of lemons that were imported. We have estimated the amounts of oranges assuming that the volume of orange imports within the total of orange and lemon imports represented a percentage similar to the arithmetic mean of the years 1893-99.

Price of oranges: Statistical Abstract. Given that up to 1892 we only have the import prices for the totality of oranges and lemons taken together, we have assumed that the relationship between this price and that of oranges individually was the same as that which existed in 1906, the only year for which we have data. Deflated by the United Kingdom consumer price index, Mitchell (1992).

Price of raisins: Statistical Abstract. Deflated by the United Kingdom consumer price index, Mitchell (1992).

Population: Mitchell (1988). Excluding the population of Ireland from 1924 onwards.

B) Table 4. Wine consumption function: France (1860-1938).

GDP: GDP at constant prices (1905-13 prices), Mitchell (1992).

Wine consumption: Annuaire Statistique de la France, p. 177*.

Price of Wine: ibid., p. 62, deflated by the French wholesale price index, Mitchell (1992).

Population: Mitchell (1992). 
C) Figure 2. Spanish exports of wine and Mediterranean horticultural products as a percentage of total exports.

Exports of wine: Estadísticas del comercio exterior, 1850-1935. Value of exports (current values) of all types of wine. In order to correct the problems associated with the official valuations as indicated by Prados de la Escosura (1986) and by Tena (1985), we have used the annual corrector coefficients calculated by these authors. We have derived them from the quotient between the corrected and uncorrected total exports series published in Tena (1989).

Exports of Mediterranean horticultural products: Value of exports (current values) of almonds, hazelnuts, peanuts, chestnuts, walnuts, prunes, dried figs, dates, raisins, other nuts, lemons, oranges, apricots, peaches, plums, pears, apples, pomegranates, other green fruits, grapes, olives, tomatoes, peppers, artichokes, asparagus, green beans, melons and watermelons, garlic and onions. We have corrected the official valuations of these in the same way as in the case of wine.

Total exports: Tena (1989).Value of total exports (current values), with the official valuations being corrected.

D) Figure 3. Volume indices of wine exports and Mediterranean horticultural products.

Own calculations based on the Estadísticas del comercio exterior, 1850-1935, at 1910 prices. We have used the same products as in Figure 2.

\section{References}

Annuaire Statistique de la France (1860-1938), Paris.

Aparicio, G. (2002) El Comercio Internacional de Productos Agrarios, 19001940, (unpub. Ph. D. thesis, Univ. of Zaragoza).

Bennett, M.K.(1957) The World's Food, Harper \& Brothers, New York.

Briggs, A.(1985) Wine for Sale. Victoria Wine and the Liquor Trade, 1860-198, B.T. Batsford Ltd, London..

Burnett, J. (1989) Plenty and Want. A Social History of Food in England From 1815 to the Present Day, Routledge, London.

Clark, C.(1957) The Conditions of Economic Progress, Macmillan, London.

Clark, G.; Huberman, M. and Lindert, P.H. (1995) A British food puzzle, 17701850, in Economic History Review, XLVIII, 2, pp. 215-237. 
Commonwealth Economic Committee (1957). Fruit : A Review, London.

Chaudhri, R. and Timmer, C.P.(1986) The impact of changing affluence on diet and demand patterns for agricultural commodities, World Bank Staff Working Papers, 785.

Department of Commerce and Labor Bureau of Statistics (1904) Foreign markets for American Fruits. Washington.

Dickey, D.A. and Fuller, W.A (1981) Likelihood ratio statistics for autoregressive time series with a unit root, Econometrica, 49, 1057-72.

Dickey, D.A. and Fuller, W.A. (1979) Distribution of the Estimators for Autoregressive Time Series with a Unit Root', Journal of the American Statistical Association, 74, 427-31.

Engle, R.F. and Granger, C.W.J. (1987) Cointegration and error correction: representation, estimation and testing, Econometrica, 55, 2, 251-76.

Estadísticas del comercio exterior de España (1850-1935), Madrid.

FAO (1948). Commodity Series. Vegetables and Fruits, No. 1., Washington.

Faugeras, J. (1931) Oranges, Citrons , Pamplemousses. Leur Culture et leur Commerce en Floride et en Californie. Paris.

Federico, G. (1992) El comercio exterior de los países mediterráneos en el siglo XIX in El desarrollo económico en la Europa del Sur: España e Italia en perspectiva histórica (Ed.) L. Prados de la Escosura and V. Zamagni, Alianza Editorial, Madrid, pp. 269-92.

Fox, K.A. (1953) The analysis of demand for farm products, Technical Bulletin United States Department of Agriculture, 1081, 1-90.

Grupo de Estudios de Historia Rural (1983) Notas sobre la producción agraria española, 1891-1931, Revista de Historia Económica, año I, 2, 185-252.

Grupo de Estudios de Historia Rural (1987) Un índice de la producción agraria española, 1891-1935, Hacienda Pública Española, 108-109, 411-22.

Hollingshead, S. R, and Wakefield, R. P. (1929) Handbook of Foreign Tariffs and Import Regulations on Agricultural Products, I. Fresh Fruits and Vegetables. Washginton.

International Institute of Agriculture, Annuaire international de statistique agricole (Rome, 1909-39).

Johansen, S. (1991) Estimation and hypothesis testing of cointegration vectors in gaussian vector autoregressive models, Econometrica, 59, 1551-80.

Liniger, M. (1962) L'orange d'Espagne sur les Marchés Européens, Les Editions du Temps, Genève.

Mitchel, B.R. (1988) British Historical Statistics, Cambridge University Press, Cambridge,

Mitchel, B.R.( 1992) International Historical Statistics. Europe, 1750-1988, Stockton Press, New York.

Moriarty, D. J.( 1930) Foreign Trade in Fresh Fruits. Washington. 
Morilla, J, Olmstead, A. L. and Rhode, P.W. (1995) "Horn of plenty": The globalization of mediterranean horticulture and the economic development of southern europe, 1880-1930, Journal of Economic History, 59, 2, 316-52.

Nelson, M. (1993) Social-class trends in british diet, 1860-1980', in Food, Diet, and Economic Change Past and Present (Ed.) C. Geissler and D.J. Oddy, Leicester University Press, Leicester, pp. 101-120.

Neumark, S.D. (1938) The Citrus Industry of South Africa, Witwatersrand University Press Johannesburg.

Nye, J.V. (1991) The myth of free-trade britain and fortress france: tariffs and trade in the nineteenth century, The Journal of Economic History, 51, 23-46.

O'Rourke, K.H. and Williamson, J. G. (2002) When did globalisation begin?, European Review of Economic History, 6, part 1, 23-50.

Oddy, D. (1976)A Nutritional Analysis of Historical Evidence: the Working-Class Diet, 1880-191', in The making of the Modern British Diet (Ed.) D. Oddy and D. Miller, Croomhelm, London pp. 215-31.

Offer, A., (1991) The First World War: an agrarian interpretation, Clarendon Press, Oxford.

Ojala, E. M. (1952) Agriculture and Economic Progress, Oxford University Press, London.

Palafox J. (1983) Estructura de la exportación y distribución de beneficios. La naranja en el País Valenciano (1920-1930), Revista de Historia Económica, año I, 2, 339-51.

Pan-Montojo, J. (1994) LaBodega del Mundo. La Vid y el Vino en España (18001936), Alianza Editorial, Madrid.

Pinilla V. and Ayuda, M.I. (2002) The political economy of the wine trade: spanish exports and the international market, 1890-1935, European Review of Economic History, 6, part.1, 51-86.

Pinilla V. and Ayuda, M.I. (2003) Horn of plenty revisited: the globalisation of mediterranean horticulture and the economic development of Spain, 1850-1935, Fifth European Historical Economics Society Conference.

Prados de la Escosura, L. (1986) Una serie anual del comercio exterior español (1821-1913), Revista de Historia Económica, IV, 1, 103-152.

Prest, A.R. (1954) Consumer's Expenditure in the United Kingdom, 1900-1919, Cambridge University Press, Cambridge.

Ramon-Muñoz, R. (2000) Specialization in the international market for olive oil before World War II'. In The Mediterranean Response to Globalization Before 1950 (Ed.) S. Pamuk, and J. G. Williamson, Routledge, London, pp. 159-198.

Ritter, K. and Guttfeld, M. (1923) World production of and world trade in table grapes, Monthly Bulletin of Agricultural Economics and Sociology, 9, 285-299. 
Schultz, T.W.( 1953) The Economic Organization of Agriculture, Mac Graw Hill, New York.

Simpson, J. (1995) Spanish Agriculture: The Long Siesta, 1765-1965, Cambridge.

Simpson, J. (2004) Selling to reluctant drinkers: the British wine market, 18601914, Economic History Review LVII, 1, 80-108.

Sournia, J. (1990) A History of Alcoholism, Basil Blackwell,Oxford.

Statistical Abstract for the United Kingdom (1846-1935), London.

Stone, R. (1954) The Measurement of Consumer's Expenditure and Behaviour in the United Kingdom, 1920-1938, vol. I, Cambridge University Press, Cambridge.

Tena, A. (1985) Una reconstrucción del comercio exterior español, 1914-1935: La rectificación de las estadísticas oficiales, Revista de Historia Económica, III, 1, 77-122.

Tena, A. (1989) Comercio exterior, in Estadísticas Históricas de España, siglos $X I X-X X$ (Ed.) A.Carreras, Banco Exterior de España, Madrid, pp. 327362.

Yates, P. L.(1960) Food, Land and Manpower in Western Europe, Macmillan, London. 


\section{TABLES}

Table 1. Main British horticultural Mediterranean and Wine Imports, 1860-1934

Almonds Grapes Raisins Oranges Tomatoes Onions Wine

\begin{tabular}{|c|c|c|c|c|c|c|c|}
\hline \multicolumn{8}{|c|}{ Imports rate of growth (\%) } \\
\hline $1860-900$ & 4.2 & 11.7 & 1.4 & 5.2 & n.a. & 8.2 & 1.1 \\
\hline $1901-34$ & 2.5 & 1.1 & 2.5 & 2.0 & 4.0 & 1.0 & -0.3 \\
\hline \multicolumn{8}{|c|}{ Per capita imports rate of growth (\%) } \\
\hline $1860-900$ & 3.3 & 10.7 & 0.5 & 4.3 & n.a. & 7.2 & 0.2 \\
\hline $1901-34$ & 2.2 & 0.7 & 2.2 & 1.6 & 3.6 & 0.7 & -0.6 \\
\hline \multicolumn{8}{|c|}{ Volume of imports , $1900=100$} \\
\hline 1860 & 18 & 1 & 58 & 14 & n.a. & 4 & 64 \\
\hline 1900 & 100 & 100 & 100 & 100 & 100 & 100 & 100 \\
\hline 1934 & 227 & 145 & 229 & 191 & 359 & 141 & 91 \\
\hline \multicolumn{8}{|c|}{ Volume of imports per capita, 1900=100 } \\
\hline 1860 & 26 & 2 & 83 & 20 & n.a. & 6 & 92 \\
\hline 1900 & 100 & 100 & 100 & 100 & 100 & 100 & 100 \\
\hline 1934 & 202 & 126 & 204 & 170 & 320 & 125 & 81 \\
\hline
\end{tabular}

Notes:

a $1860=$ average $1859-1861 ; 1900=$ average $1899-1901 ; 1934=$ average $1933-1935$. b oranges are between 1860 and 1900 oranges and lemons; 1900-1934 only oranges. c currants not included in raisins.

Sources:

Mitchell, British Historical Statistics (population).

Statistical Abstract, 1859-1935 (trade), 
Table 2. Estimations of the United Kingdom orange consumption function, 18541935

\begin{tabular}{|c|c|}
\hline Short-run & \\
\hline$\Delta \mathrm{PO}_{\mathrm{t}}$ & $0.18[.321]$ \\
\hline$\Delta \mathrm{PR}_{\mathrm{t}}$ & $-0.11[.408]$ \\
\hline$\Delta \mathrm{I}_{\mathrm{t}}$ & $1.38 *[.020]$ \\
\hline $\mathrm{D} 1 \Delta \mathrm{PO}_{\mathrm{t}}$ & $-0.76 * *[.001]$ \\
\hline $\mathrm{D} 1 \Delta \mathrm{I}_{\mathrm{t}}$ & $1.42[.153]$ \\
\hline $\mathrm{D} 2 \Delta \mathrm{I}_{\mathrm{t}}$ & $-2.10 *[.019]$ \\
\hline$\Delta \mathrm{CO}_{\mathrm{t}-1}$ & $-0.28 *[.017]$ \\
\hline$\Delta \mathrm{PO}_{\mathrm{t}-1}$ & $-0.25[.066]$ \\
\hline $\mathrm{ECM}$ & $-0.68 * *[.000]$ \\
\hline Long-run & \\
\hline 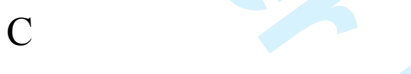 & $-9.42 * *[.000]$ \\
\hline $\mathrm{D} 1_{\mathrm{t}-1}$ & $13.87 *[.010]$ \\
\hline $\mathrm{D} 2_{\mathrm{t}-1}$ & $7.41 * *[.001]$ \\
\hline $\mathrm{PO}_{\mathrm{t}-1}$ & $0.71 * *[.000]$ \\
\hline $\mathrm{PR}_{\mathrm{t}-1}$ & $0.15[.367]$ \\
\hline $\mathrm{I}_{\mathrm{t}-1}$ & $3.05 * *[.000]$ \\
\hline $\mathrm{D} 1 \mathrm{I}_{\mathrm{t}-1}$ & $-2.94 * *[.008]$ \\
\hline $\mathrm{D} 2 \mathrm{I}_{\mathrm{t}-1}$ & $-1.61 * *[.001]$ \\
\hline $\mathrm{R}^{2}=0.98$ & $\mathrm{AIC}=-1.34$ \\
\hline $\bar{R}^{2}=0.97$ & $\mathrm{SBIC}=-0.83$ \\
\hline \multicolumn{2}{|l|}{$R_{\Delta}^{2}=0.66$} \\
\hline \multicolumn{2}{|l|}{$\bar{R}_{\Delta}^{2}=0.57$} \\
\hline LM het. $=75.81[0.356]$ & \\
\hline
\end{tabular}


$\mathrm{D}-\mathrm{W}=2.21$

$\operatorname{LM}(2)=4.16[0.124]$

Note: Values in square brackets are the p-values. $\mathrm{R}^{2}$ is given for levels and differences (denoted by $\Delta$ ). $\mathrm{D}-\mathrm{W}=$ Durbin-Watson test. $\mathrm{LM}$ het. is the White statistic to test homoskedasticity and $\operatorname{LM}(2)$ is the Breusch-Godfrey statistic to test no autocorrelation against autocorrelation of order $2 . *$ means significant at the $5 \%$ level and $* *$ means significant at the $1 \%$ level. $\Delta$ means first differences. $\mathrm{D} 1 \Delta \mathrm{P}_{\mathrm{t}}$ is a variable formed as the product of $\mathrm{D}_{\mathrm{t}}$ and $\Delta \mathrm{P}_{\mathrm{t}}$. It consists of the value of $\Delta \mathrm{P}_{\mathrm{t}}$ for each observation in the war years. $\mathrm{D} 2 \Delta \mathrm{I}_{\mathrm{t}}$ is a variable formed as the product of $\mathrm{D} 2_{\mathrm{t}}$ and $\Delta \mathrm{I}_{\mathrm{t}}$, and consists of the value of $\Delta \mathrm{I}_{\mathrm{t}}$ for each observation from 1898 to 1935 . The rest of the product dummies $\left(\mathrm{D} 1 \Delta \mathrm{I}_{\mathrm{t}}, \mathrm{D} 1 \mathrm{P}_{\mathrm{t}-1} \ldots\right)$ are formed in a similar fashion.

Table 3. Evolution of wine consumption, 1886-1929 (litres per head)

$\begin{array}{llllllllllllll}\text { UK DK } & \mathrm{N} & \mathrm{A} & \mathrm{H} & \mathrm{CH} & \mathrm{D} & \mathrm{NL} & \mathrm{B} & \mathrm{F} & \mathrm{P} & \mathrm{E} & \mathrm{I} & \text { USA }\end{array}$

$\begin{array}{llllllllllllll}1886-90 & 1.7 & \text { n.a. } & 0.8 & 24.0 & 19.0 & \text { n.a. } & 5.8 & 2.0 & 3.3 & 91.0 & \text { n.a. } 72.0 & 99.0 & 2.0\end{array}$

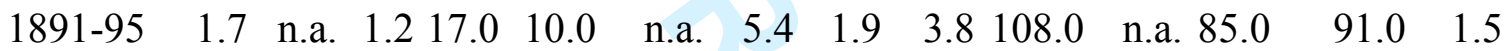

$\begin{array}{lllllllllllllll}1896-00 & 1.8 & 1.8 & 2.5 & 18.0 & 11.0 & 75.0 & 6.3 & 1.8 & 4.2 & 130.0 & 92.0 & 87.0 & 92.0 & 1.4\end{array}$

$\begin{array}{lllllllllllllll}1901-05 & 1.5 & 1.6 & 1.5 & 18.0 & 18.0 & 75.0 & 7.0 & 1.7 & 4.6 & 139.0 & 92.0 & 88.0 & 112.0 & 1.8\end{array}$

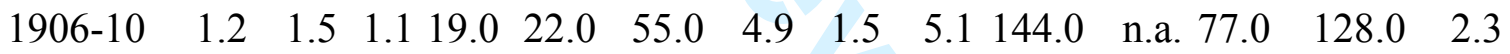

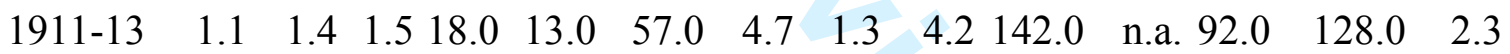

$\begin{array}{lllllllllllllll}1920-24 & 1.3 & 1.6 & 2.7 & 17.0 & 36.0 & 50.0 & 4.5 & 1.5 & 7.7 & 168.0 & \text { n.a. } 96.0 & 92.0 & 0.5\end{array}$

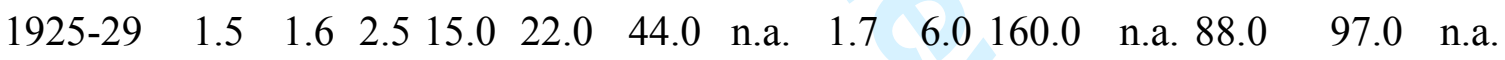

Source: Annuaire Statistique de la France UK= United Kingdom, DK= Denmark, $\mathrm{A}=$ Austria, $\mathrm{N}=$ Norway, $\mathrm{H}=$ Hungary, $\mathrm{CH}=$ Switzerland, $\mathrm{D}=$ Germany, $\mathrm{NL}=$ Netherlands, $\mathrm{B}=$ Belgium, $\mathrm{F}=$ France, $\mathrm{P}=$ Portugal, $\mathrm{E}=$ Spain, $\mathrm{I}=\mathrm{Italy}, \mathrm{USA}=$ United States. 
Table 4. Estimations of the French wine consumption function, 1860-1938

Short-run

\begin{tabular}{ll}
\hline $\mathrm{C}$ & $-0.39[.161]$ \\
\hline$\Delta \mathrm{P}_{\mathrm{t}}$ & $0.01[.651]$ \\
$\Delta \mathrm{I}_{\mathrm{t}}$ & $0.33^{*}[.011]$ \\
$\mathrm{ECM}$ & $-0.68^{* *}[.000]$ \\
\hline Long-run & \\
\hline $\mathrm{D}_{\mathrm{t}-1}$ & $4.39^{* *}[.001]$ \\
$\mathrm{P}_{\mathrm{t}-1}$ & $-0.33^{* *}[.000]$ \\
$\mathrm{I}_{\mathrm{t}-1}$ & $0.91^{* *}[.000]$ \\
$\mathrm{DP}$ & $0.12[.122]$ \\
$\mathrm{DI} \mathrm{t}_{\mathrm{t}-1}$ & $-0.69 * *[.000]$ \\
& \\
$R^{2}=0.87$ & \\
$\bar{R}^{2}=0.86$ & $\mathrm{AIC}=-107.058$ \\
$R_{\Delta}^{2}=0.65$ & $\mathrm{SBIC}=-96.8763$ \\
$\bar{R}_{\Delta}^{2}=0.60$ & \\
$L M h e t .=4.57 *[0.034]$ & \\
$D-W=1.82[<.603]$ & \\
\hline & \\
\hline & \\
\hline
\end{tabular}

Note: Values in square brackets are the p-values. $\mathrm{R}^{2}$ is given for levels and differences (denoted by $\Delta$ ). $\mathrm{D}-\mathrm{W}=$ Durbin-Watson test. * means significant at the $5 \%$ level and $* *$ means significant at the $1 \%$ level. $\Delta$ means first differences. $\mathrm{DP}_{\mathrm{t}-1}$ is a variable formed as the product of $\mathrm{D}_{t}$ and $\mathrm{P}_{\mathrm{t}-1}$, and consists of the value of $\mathrm{P}_{\mathrm{t}-1}$ for each 
observation after the war. The other dummy variable, $\mathrm{DI}_{\mathrm{t}-1}$, is formed in a similar fashion.

Table 5. Spanish World trade quota in horticultural Mediterranean products and wine

\begin{tabular}{lrrrr} 
& $1909-13$ & $1925-28$ & $1929-32$ & $1933-35$ \\
\cline { 2 - 5 } Oranges & 65.6 & 59.3 & 61.0 & 48.9 \\
Lemons & 1.2 & 5.5 & 6.2 & 9.1 \\
Table Grapes & 33.0 & 25.8 & 25.7 & 25.9 \\
Raisins & 9.8 & 6.4 & 5.2 & 3.8 \\
Wine $^{\mathrm{a}}$ & 18.8 & 22.5 & 18.5 & 9.3 \\
Wine $^{\mathrm{b}}$ & 32.4 & 42.3 & 43.7 & 34.3 \\
\hline
\end{tabular}

Notes:

${ }^{a}$ World trade in wine including French Maghreb exports to France as international trade

${ }^{\mathrm{b}}$ World trade in wine considering French Maghreb exports to France as domestic trade Source:

International Institute of Agriculture, Annuaire International. 


\section{FIGURES}

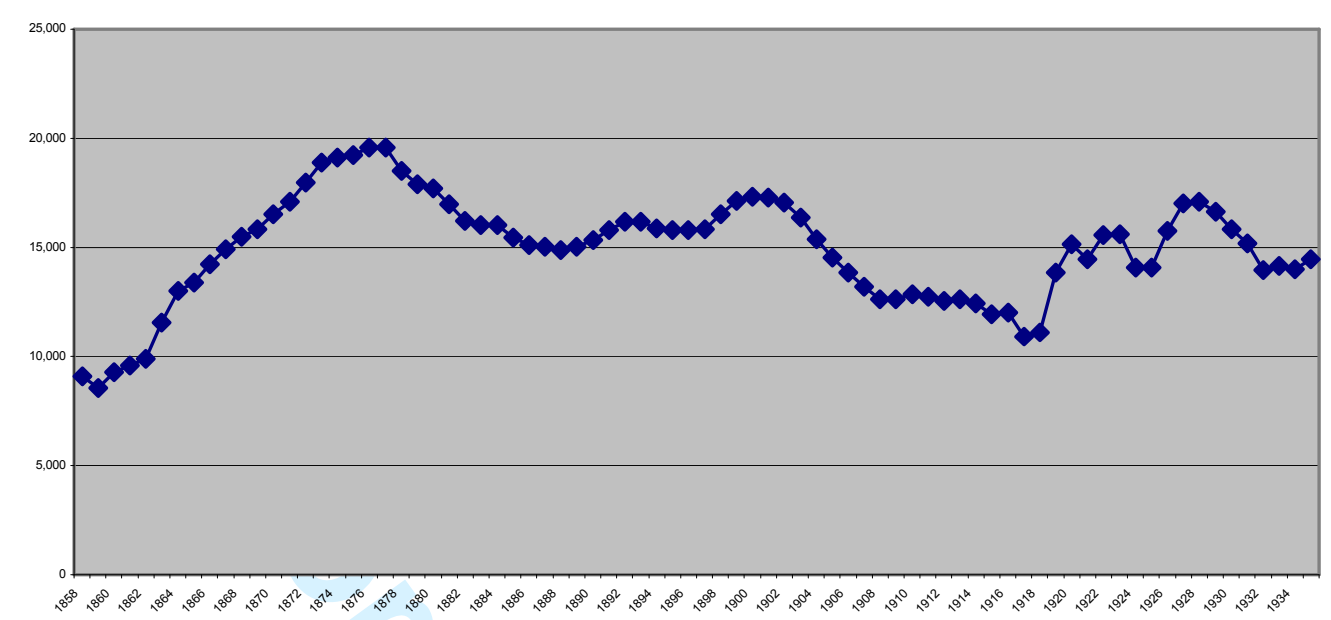

Figure 1. United Kingdom imports of wine, 1854-1935 (thousands of gallons, five year averages)

Source: Statistical Abstract.

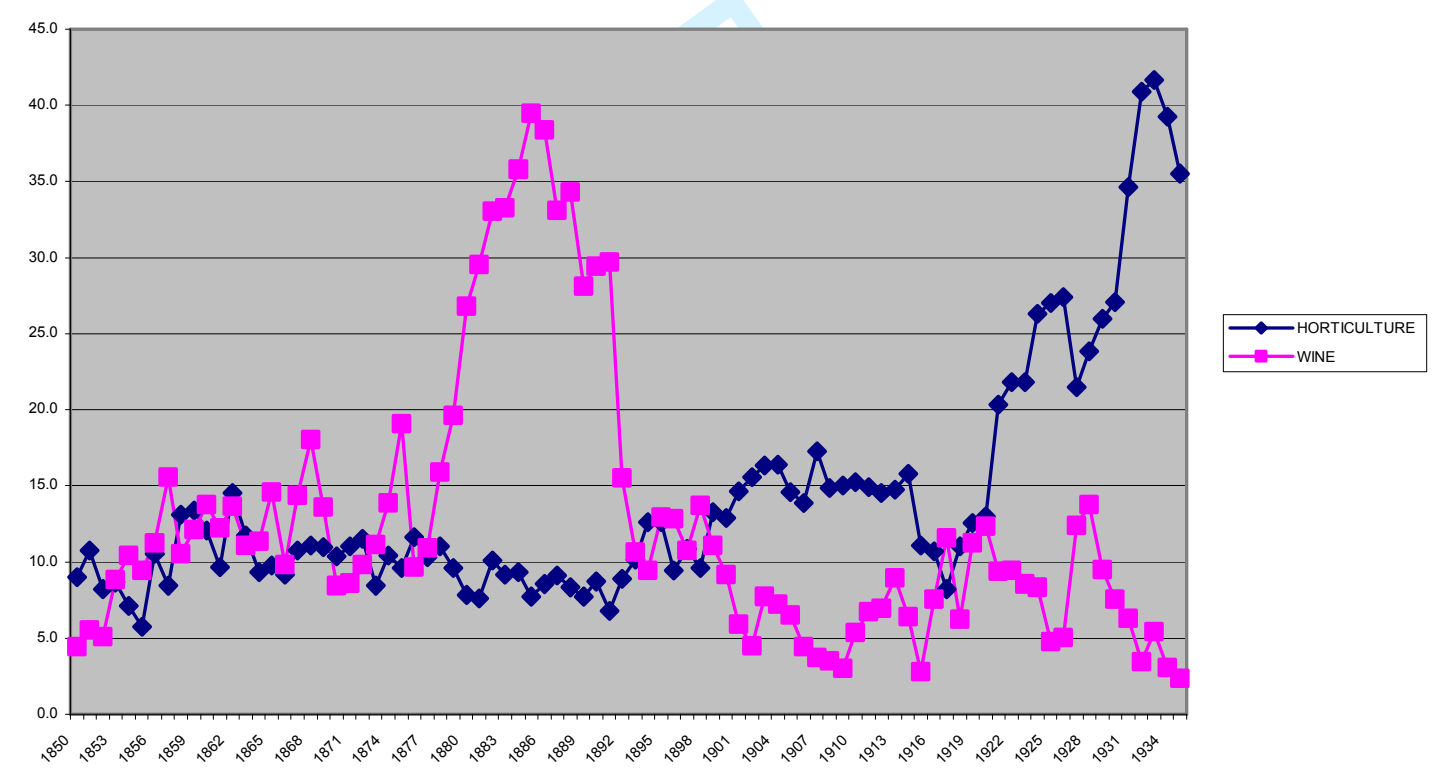

Figure 2. Spanish exports of Mediterranean horticultural products and wine as a percentage of total Spanish exports, 1850-1935

Source: Appendix. 


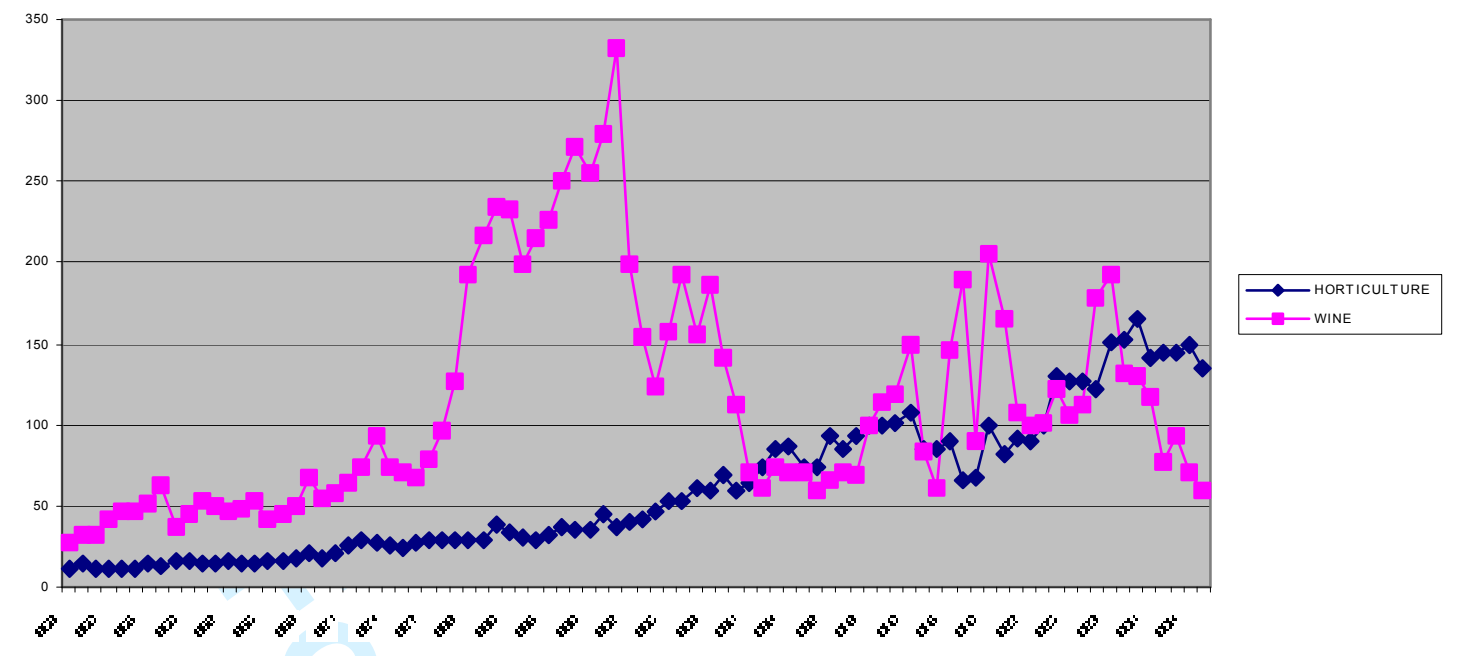

Figure 3. Volume indices of Spanish exports of Mediterranean horticultural products and wine $(1900=100)$

Source: Appendix. 
Market dynamism and international trade:

a case study of Mediterranean agricultural products, 1850-1935

\title{
VICENTE PINILLA and MARÍA-ISABEL AYUDA
}

- Vicente Pinilla: Department of Applied Economics and Economic History, University of Zaragoza. Gran Via 4 (50005) Zaragoza (Spain).

- María-Isabel Ayuda. Department of Economic Analysis. University of Zaragoza. Gran Via 4 (50005) Zaragoza (Spain).

Short title: Market dynamism and international trade

\begin{abstract}
:
This paper concentrates on analysing the rightward shifts of the demand curve for Mediterranean agricultural products from 1850 to 1938 . We have found that such shifts were especially conditioned by the different income elasticities of demand and by changes, or otherwise, in consumer preferences. Our aim is to show that there was an initial conditioning factor for the producer countries to take full advantage of these potential growth opportunities, namely the size of such shifts. The case of Spain serves to compare the effects derived from the evolution of the demand for two groups of products: Mediterranean horticultural products and wine.
\end{abstract}

- Address for correspondence: Vicente Pinilla. Department of Applied Economics and Economic History. Gran Vía 1-3 (50005) Zaragoza (Spain). Email:vpinilla@unizar.es. 


\section{Market dynamism and international trade: a case study of Mediterranean agricultural products, 1850-1935}

\section{Introduction}

The onset of the industrialisation process in a significant number of countries, above all in Western Europe, during the course of the nineteenth century gave rise to a whole series of economic effects. One of the most significant was the increase in the volume of international trade. This expansion was led by the process of globalisation and the associated price convergence (due to the sharp fall in transport costs and trade liberalisation) and by outward shifts in demand or supply curves (O'Rourke and Williamson, 2002).

In this context, the economic growth enjoyed by the more developed countries generated an increase in demand for products which they could either not produce themselves, or which could be obtained at lower prices on the international market. As a result, opportunities opened-up for the less developed countries to give momentum to their development through participation in international trade.

Focusing on Europe, considerable prominence has been given to the possibilities for the Southern European countries. At the same time, the responses of these countries to such possibilities and to the obstacles they had to face have attracted much interest. It has been suggested that globalisation not only opened up these opportunities but, by extending the production of traditionally Mediterranean products to other areas, could also have led to greater competition or to the establishment of trade barriers to protect nascent extra-European production (Federico, 1992; Morilla, Olmstead and Rhode, 1995; Pinilla and Ayuda, 2002; Ramon-Muñoz, 2000).

Against this background, this paper concentrates exclusively on analysing the rightward shifts of the demand curve for Mediterranean agricultural products. In this way, our aim is to show that there was an initial conditioning factor for the 
producer countries to take full advantage of these potential growth opportunities, namely the size of such shifts. This was a necessary but not sufficient condition for generating active international trade that was capable of driving the economic development of the Southern European countries. Logically enough, not all the products offered the same possibilities from the point of view of demand, and nor did they give rise to the same effects in the development process, in that the potential linkages conditioned the impact of the increase in trade on the economy as a whole.

In the specific case considered here, we shall compare the sizes of the demand curve shifts, and the reasons for them, for two products that had decisive weight in the agricultural economies and foreign trade of these countries, that is to say, wine and Mediterranean-type fruit and vegetables.

Our hypothesis is that both types of products exemplify very different growth possibilities that were made available by international trade. Thus, although by the time of World War II wine had still not become a mass consumer product beyond the borders of the traditional consumer countries (or populations of this origin), Mediterranean horticultural products had enjoyed a quite extraordinary diffusion outside their areas of production.

Logically enough, the evolution of international demand depended on a broad range of factors, associated with economic, social, cultural and other types of variables. In this paper, our objective is to concentrate exclusively on the relationship between the increase in per capita income and consumption, without in any way seeking to undervalue the impact that other factors may have had and, indeed, making reference to them ${ }^{1}$. In our view, the approach we have chosen allows us to isolate what was, in our judgement, a key variable in the evolution of demand. Such a viewpoint also has the advantage of permitting an econometric treatment of the available quantitative data, in such a way that we can establish with some precision the long-run relationship between both variables.

In order to meet our objective, the rest of the paper has been organised as follows. We first study the consumption of Mediterranean horticultural products

1 An extensive international literature supports our choice of this option: see, for example (Chaudhri and Timmer, 1986). 
and the evolution thereof, before transferring this analysis to the case of wine. The paper closes with a review of the main conclusions.

\section{Fruit and vegetables}

A dynamic market

A key element in the globalisation of the production and trade in Mediterranean horticultural products is represented by the very marked increase in their consumption. Although such goods were initially consumed by very limited sections of the population in the countries of north-western Europe, the increase in supply in response to the excellent possibilities and profits coming from their trade, and the increase in incomes enjoyed by the population of these countries in the second half of the nineteenth century, opened the possibility of their consumption to the ever-increasing middle class and, subsequently, to the working class. Thus, what were once considered exotic products became habitual elements in the diets of the peoples of northern Europe and North America. Obviously, the increase in the populations of these industrialised countries between 1850 and 1938 also contributed to the increase in demand.

In the epochs before the onset of the various industrialisation processes, contrasts in the composition of the diets consumed by the populations of the different European countries were basically defined by their endowments of natural resources, given that long-distance trade in foodstuffs was very limited. As is well known, this was linked essentially to the firmly established trade in cereals, albeit in limited amounts as compared to those traded subsequently.

The improved possibilities for the cultivation of fruit and horticultural products in the countries of southern Europe increased their importance in the diet consumed by their populations.

Differences in terms of calories consumed by the inhabitants of the diverse areas of Europe were probably not significant prior to industrialisation (Yates, 1960). However, the marked increase in the per capita income of the countries most involved in the industrialisation process meant that the diets of the European peoples, especially those of western and northern Europe, began to change. The first of these changes took the form of an increase in their consumption of 
calories. This initially came from the most habitual foodstuffs. Subsequently, it resulted from the diversification of the diet of these populations groups, who began to consume products that were already available from their respective areas but to which they had traditionally, and for economic reasons, enjoyed either very limited access, or none at all. Finally, there was an increase in the consumption of commodities whose production was either very limited in these areas or simply not viable from the ecological or economic point of view.

Once acceptable levels of consumption had been assured, this diversification of diet led to a fall in the consumption of traditional foodstuffs, such as those derived from cereals and potatoes. By contrast, meat and livestock products in general, together with oils and fats, sugar, fruit and vegetables and beverages derived from cocoa, coffee or tea, were the commodities that benefited most from this diversification.

Consumption of fruit and vegetables in the industrialised countries tended to increase from levels that were relatively very low. This was especially the case with respect to fruit, the consumption of which generally grew much more rapidly than that of fresh vegetables. Despite this strong growth, and once high levels of development had been reached, the part represented by the consumption of fruit and vegetables in the total calories consumed was considerably higher in the countries of southern Europe, which still had very low levels of development, than in those of north and central Europe, where diets had already achieved levels appropriate to developed countries ${ }^{2}$. This reveals the persistence of significant differences in the types of diets despite the dietary changes that had come about as a consequence of the increase in the income levels of the developed countries. These differences were linked essentially to the respective national traditions. In general, they are a reflection of the fact that the populations of each country tended to consume more of the foodstuffs actually produced there, and that dietary

\footnotetext{
${ }^{2}$ According to Yates (1960), utilising FAO data for 1957, in the three types of ideal diet that he identified, namely that of north, central and southern Europe, fruit and vegetables represented $5.2 \%, 6.3 \%$ and $11.8 \%$, respectively, of the total consumption of calories. The central diet was $6.8 \%$ lower than the northern diet in terms of calories consumed, whilst the southern diet was $17.5 \%$ lower than the northern and $11.5 \%$ lower than the central diets.
} 
diversification might mean changes in function of what was the previous pattern of consumption. That is to say, an increase in income tended to translate into an increase in the amounts of the products that had traditionally been consumed to a lesser extent.

The analysis of the foreign trade statistics of the United Kingdom, the main importer of these products throughout the period under analysis, with respect to a group of very representative commodities from amongst those being considered, clearly demonstrates the rapid increase that took place in imports of fruit and vegetables coming from a Mediterranean origin. Given that the United Kingdom's production of these foodstuffs was either very small or nil, these import data represent an excellent approximation to the variation in their consumption.

INSERT TABLE 1.

Table 1 shows that the rate of increase in imports of some of the most representative horticultural products from the Mediterranean was extremely high. This rate was in fact much higher in the second half of the nineteenth century than the first third of the twentieth, which is perfectly understandable if we bear in mind that the starting levels were very low. In absolute terms, the increase in imports was truly impressive.

From Table 1 we can also appreciate that the increase in imports due to the rise in per capita consumption was much more important than the simple increase in the population. This strong increase in imports per inhabitant is a clear reflection of the growth in per capita consumption of fruit and vegetables on the part of the population of the United Kingdom. Drawing on data from the twentieth century (given that we lack data for earlier periods), we find that whilst spending on foodstuffs, at constant prices, rose by some 12.3 per cent between 1900 and 1935 , spending on fruit and nuts increased by no less than 62.3 per cent and on vegetables by 47.3 per cent during the same period (Stone, 1954).

We may draw the conclusion that in the long-term the increase in the consumption of fruit significantly exceeded that of foodstuffs as a whole. Even so, the per capita consumption of fresh fruit in the United Kingdom during the years prior to the Second World War was only 62.4 per cent of the Australian level and 
57.6 per cent per cent of that of the United States (1934-8 for the United Kingdom and 1935-9 for the United States)( Commonwealth Economic Committee, 1957).

Turning to United States data, we again find a significant increase in the consumption of fruit and vegetables and, above all, of certain processed products, such as preserves or juices, during the first third of the twentieth century. The increases that Fox calculates for a number of specific products between 1909 and 1950 are also spectacular. Thus, the per capita consumption of table grapes had multiplied by nine, that of fruit preserves by seven, and that of fruit juices by twenty nine. By contrast, during the same period the consumption of wheat flour had fallen by 33 per cent, that of corn flour by 70 per cent and that of potatoes by 50 per cent(Fox, 1953) ${ }^{3}$. Thus, during the years prior to the Second World War the United States had the highest per capita consumption of these types of products of all the industrialised countries (Hollingshead and Wakefield, 1929). If we further take into account the significant growth in the population of the United States, it is clear that this country was the main international consumer of Mediterranean horticultural products.

The cases of the United Kingdom and the United States are very representative of what occurred in the developed countries. OEEC studies have concluded that between 1913 and 1957 the rate of growth in the annual per capita consumption of fruit significantly exceeded that of any other type of foodstuffs, whilst vegetables, although not enjoying such dynamic performance, also occupied a relatively good position (Yates, 1960).

\section{Increase in income and growth in consumption}

The explanation for the strong growth in the per capita consumption of Mediterranean horticultural products lies above all, although not exclusively, in the fact that such consumption responded comparatively well to changes in income. The relatively high income elasticity of demand of these products as compared to other foodstuffs was, therefore, a key element in this growth.

\footnotetext{
${ }^{3}$ Shultz (1953) has also verified that between 1909 and 1949 the products which enjoyed the greatest increase in per capita consumption were citrus fruits and tomatoes $(+54 \%)$.
} 
Other factors that also acted as a motor for this increase in consumption were the publicity campaigns launched by the fruit distributors in countries such as the United Kingdom, France and the United States ${ }^{4}$. These campaigns, which were only relevant from 1920 onwards, frequently highlighted scientific discoveries that placed emphasis on the significant contribution of vitamins or minerals offered by these products and, therefore, their importance for nutrition and health. To that end, they used members of the medical profession and scientists to act as "credible" broadcasters of such discoveries (FAO, 1948). Particularly interesting were the efforts made by Californian producers to promote the consumption of citrus fruits using a variety of innovative ideas, such as spreading the popularity of fruit juice squeezers, at first, manual, and later, electric-powered, or using wrapping paper for oranges that contained recipes for the inclusion of these products in more elaborate dishes.

Furthermore, the urbanisation process and the decline in the need for "strong" foodstuffs with the arrival of a pattern of life that demanded less physical effort, also favoured the growth in the consumption of these products ${ }^{5}$. In summary, changes in working and living conditions encouraged suitable nourishment of a less heavy kind (Ritter and Guttfeld, 1932). Whilst this wide range of causes, all of them linked to industrialisation and economic development, acted as a motor for such consumption, there is no doubt that one of the main consequences of this development, the increase in per capita income, played an absolutely determining role.

Fruit was initially a luxury product, with consumption tending to increase above all for the high income population group. At the end of the nineteenth century, it was still to some extent regarded as a luxury good in the United

${ }^{4}$ Liniger (1962) for France; Moriarty (1930) for the United Kingdom; Faugeras (1931) for the United States. The emergence of modern nutritional science in the second part of the nineteenth century played an important role in shaping dietary changes in industrialised countries. In the case of fruits, the importance of vitamins began to be understood in the period between the 1880s and World War I. See Offer (1991).

5 This theme has been analysed for a period immediately prior to the one considered here by Clark, Huberman and Lindert (1995). 
Kingdom, France and Germany and, although desired by the population as a whole, lower income population groups continued to have only limited access to such products (Department. of Commerce, 1904; Liniger, 1962).

Highlighting the sharp differences in this regard between the different social groups, the available data on food consumption and diet for the United Kingdom, show how low incomes dramatically limited choice (Burnett, 1989; Oddy, 1976). In the face of the uncertain dietary and food situation affecting a significant part of working class families, fruit and vegetables were normally an unattainable option. Thus, there were frequently differences of as much as ten times in spending on fruits between the highest and the lowest income groups (Nelson, 1993). The fruit consumed by the working class consisted essentially of currants (habitually used for making "roly-poly") and jam. The fall in the prices of bread and meat as a consequence of the sharp increase in imports from the New World and Australia left a significant part of income available for the purchase of other foodstuffs, from amongst which fruit and vegetables, together with eggs and dairy products, benefited the most. In the case of the United Kingdom, it is interesting to note that by the middle of the 1930s fruit was one of the foodstuffs with the steepest gradient of consumption in terms of income, with consumption being eight times higher in the highest income decile than in the lowest (Neumark, 1991). During this same period, 1936-7, the study made by Sir William Crawford also confirmed the dramatic differences in the consumption of fruit, above all in the two extreme classes of the five into which the population was divided on the basis of their incomes. Notably, there was a clear convergence between the first three of these classes (25 per cent of the population), who enjoyed a very widespread consumption of fruit, and the last two ( 75 per cent of the population) in which fruit was consumed in only a very small number of families (Burnett, 1989). In the United States, by 1942 the differences between income groups in the consumption of these products were considerably smaller, at least in urban homes (Ojala, 1952).

The well-known work of Stone concluded that the income elasticity of these products was relatively high when considered as foodstuffs. Thus, using United 
Kingdom budgetary surveys for 1936-7 and 1937-8, he calculated a value of 1.34 for fruit and 0.86 for vegetables, as compared to 0.53 for foodstuffs as a whole ${ }^{6}$.

The income elasticities of demand for the same period, 1913-1958, and for the OECD countries, again show the highest value for fruits, 1.97, and a much more moderate one for vegetables, 0.54 (Yates, 1960).

Though they reflect values that were high in the context of foodstuffs, the elasticities reported in these works unfortunately refer to years subsequent to those considered in this paper. By this time in fact, the consumption of Mediterranean horticultural products enjoyed wide-spread popularity among the populations of the industrialised countries.

In our case, we propose to extend the analysis of the relationship between income and the consumption of these types of products to the totality of the period under analysis, that is to say, to the years $1850-935$. To that end, and as the most representative product of Mediterranean fruit and horticultural production, we have chosen the case of the consumption of oranges in the United Kingdom, which reflects a number of characteristics that justify our choice. First, the United Kingdom did not produce oranges, which means that we can approximate its imports to national consumption. Furthermore, prior to the outbreak of the Second World War, oranges and apples were by far the most commonly consumed fruits, with annual consumption exceeding 20 pounds per person, while no other fruit normally reached 5 pounds, save bananas which ranged between 10 and 15 pounds (Neumark, 1938). The results that we obtain will hopefully be of use in a number of areas. First, to validate those obtained in studies cited earlier. Secondly, and given the length of the period covered, they will allow us to better understand the long-term relationships between the consumption of these products and income, not only for the United Kingdom but also for other countries that were undergoing the industrialisation process. Finally, we should recall that all previous

\footnotetext{
${ }^{6}$ Stone (1954). The income elasticities of demand of the individual products were as follows: various fresh fruits and nuts (1.62), tinned and bottled fruit (1.34), apples (1.33), bananas (0.95), oranges (0.92), fresh vegetables and pulses (0.93), tubers (excluding potatoes) and tomatoes (0.85), dried fruits (0.75), tinned and bottled vegetables (0.70) and onions (0.22).
} 
studies of this type have been carried out either for the inter-war years or for those following the Second World War, that is to say, times when the level of development of the industrialised countries could be considered as high.

\section{Econometric analysis of orange consumption in the United Kingdom}

Thus, for the period 1854-935 we propose a model in which the dependent variable is the per capita consumption of oranges $\left(\mathrm{CO}_{\mathrm{t}}\right)$, with the independent variables being income per capita $\left(\mathrm{I}_{\mathrm{t}}\right)$, the price of oranges $\left(\mathrm{PO}_{\mathrm{t}}\right)$ and the price of raisins $\left(\mathrm{PR}_{\mathrm{t}}\right)$. As a consequence, we are assuming that the consumption of oranges is determined by the evolution of per capita income, by their price and by the price of their main substitute product ${ }^{7}$. In the models all the variables are in natural logarithms. We also introduce two dummy variables, $\mathrm{D} 1_{\mathrm{t}}$ and $\mathrm{D} 2_{\mathrm{t}}$. The first, $\mathrm{D} 1_{\mathrm{t}}$, seeks to reflect the particular situation of the years covering the First World War and the immediate post-war years, where we assume that first the war itself, later the submarine blockade and finally the post-war era all represent a somewhat anomalous situation. The second, D2 $2_{t}$ seeks to determine whether some differences existed between the consumption elasticities before and after 1896, given that the Chow test indicates a structural change.

In the econometric analysis, we first studied the individual behaviour of the three series by using the graphics, the correlograms and certain tests as the Dickey-Fuller test (Dickey and Fuller, 1979, 1981). The unit root tests show that all variables in level form have a unit root. Using the method suggested by EngleGranger and Johansen we consider that the variables are cointegrated (Engle and Granger, 1987). Hence the error correction form is an appropriate model.

The error correction model can be estimated either by the maximumlikelihood estimation of the short-run and long-run parameters, or by using the two-step method suggested by Engle-Granger (Engle and Granger, 1987). The two-step method first estimates the long-run parameters as the equilibrium

${ }^{7}$ For the inter-war years, Stone introduced dried fruits, bananas and fresh vegetables as substitute products. Although the substitution elasticities obtained were all positive, dried fruits being the highest, none of them were significant in the final analysis. Stone (1954). 
relationship in level form. The estimate of the residual vector thus obtained is then used in the second step estimation of the error correction mechanism and, thus, we obtain the short-run parameters. In this study we use the first method and estimate all parameters simultaneously, with this approach yielding efficient parameter estimates (Johansen, 1991). The results are presented in Table 2.

\section{INSERT TABLE 2}

After estimating different models, we have chosen that which appears in Table 2, given that all the variables in the model are significant at 5 per cent save for the orange and raisins price variables in the short-run and the raisins price variable in the long-run. The chosen model does not exhibit either heterocedasticity or autocorrelation problems and, furthermore, has the smallest value of the AIC (Akaike Information Criterion) and SBIC (Schwartz Bayesian Information Criterion), and the biggest value of the adjusted $\mathrm{R}^{2}$.

The most noteworthy results of this analysis are the very high income elasticities obtained for the second half of the nineteenth century (3.05), whilst those corresponding to the first third of the twentieth, although lower, are nevertheless significantly higher than those obtained in the studies cited earlier for a similar or very proximate period of time (1.99). Thus, during the second half of the nineteenth century, decades that we might consider as reflecting the dramatic spread of these types of products in the markets of the industrialised countries, increases in income translated into much sharper increases in demand. Furthermore, the lower levels of income present in the first period also help to explain the greater elasticity it reflects. This result is in line with that forecast by Engel in 1888 when he formulated his well-known law, and verified subsequently by authors such as Clark or Shultz when further extending this line of research (Clark, 1957; Shultz, 1953).

The high elasticity of fruit corresponding to the industrialisation phase of the European countries would appear to confirm, as indeed some pioneering works had already suggested, that there could have been a 'hierarchy' of food categories on the basis of costs per calorie: thus, 'as incomes increase, people would move down the hierarchy, their food budget share of preferred (i.e., costlier) foods would rise with increasing incomes' (Chaudhri and Timmer, 1986). 
Bennett established a calorie-price hierarchy made-up of eight groups, with fruit and vegetables appearing at its head (Bennet, 1957) ${ }^{8}$.

In the light of the above, it is easy to appreciate the opportunities that had been opened to producers in these markets. As a result, agricultural specialisation in this direction was an option available to the countries of the Mediterranean periphery of Europe as a means to take full advantage of the potential offered to them by international trade.

The surprising sign of the price elasticity (unless our price data suffers from problems) can, we believe, be explained by the evolution of the price and consumption series. Whilst the increase in consumption coincided with a significant fall in prices until some years prior to the end of the nineteenth century, the subsequent relationship between both is more complex. The new falls in prices that took place immediately following this period coincided with a standstill in consumption, whilst during the First World War the relationship is as expected (high prices implying a fall in consumption) and, thereafter, increases in prices took place simultaneously with a sharp increase in consumption. It could be argued that if, this fall in prices might have favoured the extension of consumption up to the last decade of the nineteenth century, from this time onwards the consumption of oranges by families that had adopted this product as part of their habitual diet was not influenced by prices. Indeed, even at times of price increases, consumption itself increased. In explaining the price inelasticity of consumption of oranges, it should be remembered that they are a difficult product to substitute. Not only did consumers identify them as a clearly different product from the rest, but in the winter season the range of alternative fruits was limited.

\section{Wine}

\footnotetext{
${ }^{8}$ The universal character of this hierarchy has been questioned. However, in 1975, and for countries with very different levels of development fruit and vegetables were again habitually placed at the head of this hierarchy. See Chaudhri and Timmer (1986).
} 
The evolution of wine consumption: divergent patterns

Wine has been a traditional product of the Mediterranean basin. Within this part of the world, Portugal, Spain, France and Italy in particular were the main producers and consumers. The cultural tradition of wine consumption in this region is linked to the presence of the appropriate climatic conditions for its development. However, the international trade in wine, of which we have knowledge dating from at least Greco-Roman times, made possible its diffusion into other areas of Europe.

In spite of this trade, in the last quarter of the nineteenth century wine was the predominant alcoholic beverage only in the countries of Southern Europe. In Northern and Central Europe, beer and spirits prevailed. In countries with populations of European descent, the patterns of consumption of the countries of origin were usually repeated. For example wine prevailed in Argentina, but beer was the predominant beverage in the United States and Canada. Differences in national preferences have been explained on the basis of economic factors, such as the availability of the product, poor market integration, relative prices, etc, and/or based on cultural or anthropological factors, such as tradition, religion, fashion, etc.

Interestingly, the increase in wine consumption between 1850 and 1938 chiefly took place in the traditional wine-consuming countries, whilst the initial increase in wine consumption in the countries of Northern and Central Europe stopped towards the last quarter of the $19^{\text {th }}$ century at relatively very low levels ${ }^{9}$.

Consequently, we can conclude that only in a small corner of the world, namely the countries abutting the north-western shore of the Mediterranean, was wine considered to be a product of mass consumption. This was the case in Portugal, Spain, France, Italy and French and Italian speaking Switzerland, where per capita average annual wine consumption was above 50 litres. Only in a few other countries, such as Argentina, Uruguay, Chile, southern Brazil and Greece

9 Pan-Montojo (1994) confirms that between 1840 and 1870 there was a doubling of the per capita consumption of wine in the UK, Belgium, the Netherlands and the Scandinavian countries. 
was wine consumption of any significance. In the rest of the world, if wine was consumed at all, it was consumed by the high-income classes.

\section{INSERT TABLE 3}

The case of the United Kingdom represents an excellent example of what occurred in those countries where wine had not become a mass consumption product. Using import data for the United Kingdom, we can verify that between 1855 and approximately 1875, wine imports increased sharply, more than doubling over the period (Briggs, 1985; Nye, 1991). This increase could be connected with the tariff reduction on French wines in 1860 , following the trade agreement between France and the United Kingdom. In addition, there were further tariff reductions in 1861 and 1862. The expansion in wine consumption did not imply a decline in the consumption of beer or spirits. On the contrary, this decline it happened at the same time, although faster in the case of the latter. From 1875 until the beginning of the twentieth century, beer and spirit consumption remained relatively high, before suffering a sharp decline (see Figure 1).

\section{INSERT FIGURE 1}

Why did the growth in British wine imports halt after 1875, even though they were still small in relation to its population? The answer lies in the fact that until the Second World War and for some decades thereafter, wine consumption in Great Britain was restricted to a small segment of the population which enjoyed high per capita income. Thus, wine was never a real alternative to the traditional consumption of beer for the majority of the middle and lower classes ${ }^{10}$. It is similarly significant that British preferences focused on fortified wines, such as sherry and port, and sparkling wines, such as champagne, while table wines had less prominence. Among the table wines, the most important were the clarets from Bordeaux. These were in general wines of both high quality and price, which made their diffusion more difficult. The price differences between the types of wine most commonly consumed in the United Kingdom and ordinary table wine

${ }^{10}$ Briggs (1991) quotes Leoni who calculated that in 1880 the working classes consumed $75 \%$ of all beer and spirits consumed in the country, but only $10 \%$ of the wine. 
were particularly marked with sherry, for example, costing up to ten times more per litre than ordinary table wine (Simpson, 1995).

The available data on per capita consumption in Great Britain is similarly conclusive. Between 1870 and 1938, wine expenditure in the United Kingdom ranged from between 5 and 10 per cent of the total expenditure on alcoholic beverages, decreasing with the passage of time (Prest, 1954; Stone, 1954). Per capita consumption also declined in the same period, and likewise consumption of all other alcoholic beverages during the first third of the twentieth century. The main reasons why wine consumption did not expand in Great Britain during the period were the absence of any tradition of wine consumption, unawareness of the product and its high price in comparison to beer ${ }^{11}$. According to Simpson, the difficulties in establishing objective measurements of quality by way of which consumers could evaluate the different wines, together with the significant variations in that quality and the frequent adulteration of the product, also made its diffusion more difficult in the British market (Simpson, 2004).

The French case is particularly illustrative of the opposite trend. France was the country with the highest per capita consumption in the world. The study of the French case will help us to understand what happened in countries in which wine had a similar importance in terms of consumption.

During the "Ancien Regime", wine consumption in France was low among the popular classes and high among aristocrats, the clergy and the bourgeoisie. Low per capita income and a high relative price were the main obstacles to the increase in wine consumption. High transport costs and poor market integration generated very different regional consumption patterns and much higher levels of per capita alcohol consumption in producing regions. From approximately the middle of the $19^{\text {th }}$ century and until the 1920 's, two trends emerged with respect to wine consumption in France. First, per capita consumption grew substantially and secondly, some degree of convergence in consumption patterns took place between north and south, rural and urban areas and different social classes (Sournia, 1990).

\footnotetext{
${ }^{11}$ Briggs (1985) and Nye (1991) noted that the British preference for beer and gin consumption over wine must also be linked to the discriminatory British trade policy established in 1670, which continued for almost two centuries.
} 


\section{Explaining the growth of wine consumption}

It is significant that the per capita wine consumption in France more than doubled between 1860 and the years prior to the First World War. After a slight decrease, as a consequence of the war, consumption levels almost recovered their pre-war levels, although these were never exceeded.

Our hypothesis to explain the evolution of wine consumption in France is that the strong increase in per capita income was translated into an increase in wine consumption. The growth in per capita income was the result of the economic changes brought about by the industrialisation of the country. The construction of the railroad network resulted in better communications, which allowed greater accessibility to products from distant regions at low prices. The increased commercialisation of wine over long distances was also facilitated by improvements in the techniques for producing and preserving wine ${ }^{12}$.

To analyse this hypothesis we have used aggregate time series to estimate the short-run and long-run responsiveness of per capita wine consumption (W) to the wine price $(\mathrm{P})$ and to French per capita real income (I). That is, we are assuming that per capita wine consumption is determined by the evolution of French per capita income and by its price. In the models all the variables are in natural logarithms. We have used data for the years 1860-913, 1920-38. Data from 1914 to 1919 are not reliable because of the First World War. We also introduce a dummy variable (D), which seeks to determine whether any differences exist between elasticities before and after the First World War ${ }^{13}$.

As in the case of oranges, the econometric analysis first considers the individual behaviour of the three series by using the graphics, correlograms and also certain tests, such as the Dickey-Fuller (Dickey and Fuller, 1979, 1981). The unit root tests show that all variables in level form have a unit root. Using the

\footnotetext{
${ }^{12}$ It should be remembered that Louis Pasteur's important research on the production and preservation of wine was published in 1866 .

${ }^{13}$ For the last few decades there are several econometric analyses of alcohol beverage demand. See, for example, Blaylock and Blisard (1993), Duffy (1983) and Selvanathan and Selvanathan (2004).
} 
method suggested by Engle-Granger and Johansen, we may establish that the variables are cointegrated (Engle and Granger, 1987; Johansen, 1991). As in the previous case, we have used the error correction model. Using the maximumlikelihood estimation of the short-run and long-run parameters, the results obtained are presented in Table 4.

\section{INSERT TABLE 4}

After estimating various different models, we have chosen the one given in Table 4, because it exhibits the smallest value for the AIC (Akaike Information Criterion) and SBIC (Schwartz Bayesian Information Criterion), and the biggest value for the adjusted $\mathrm{R}^{2}$.

On the basis of this econometric analysis we may conclude that the increase in real income enjoyed by the French population explains, in part, the strong growth in wine consumption in France from about the middle of the nineteenth century up to the Second World War. This means that the population translated the long-run income increase into a higher demand for wine. The short-run income variations also affected consumption, but not to the same extent. In the inter War period, we may note a limited response of consumption to variations in per capita income. This may be interpreted as the French having incorporated wine consumption into their everyday diets, and not substantially modifying this practice in the face of small variations in their income. The comparison between the estimated elasticities of wine and oranges, respectively, in France and the United Kingdom is significant. The differences are important and point to very distinct rhythms in the evolution of their demand. This is particularly so if because in the case of wine we have chosen a country in which consumption grew significantly, but which, at the same time, is hardly representative of the more industrialised countries. Finally, the incidence of long-run price variations over wine consumption, whilst significant, is not particularly large. This may be interpreted as showing that the French people had come to consider wine as an everyday consumption good.

Accordingly, we can conclude that wine consumption grew mainly in those countries in which it had traditionally been drunk. We have verified, using the French case, how the increase in wine consumption in those countries was mostly determined by growth in per capita income. In the rest of the world, wine 
consumption grew in those countries that received immigrants from Southern Europe. Everywhere else, the increase in wine consumption was either not large, or simply did not occur. In the industrialised countries (excluding France), with higher per capita incomes, the increase in consumption was significant, especially in the decades after 1850, although later the trend did not continue. The attractive prospects from the demand side that existed in the second half of the nineteenth century tended to evaporate in the first third of the twentieth century. In some developed countries, the rapid development of wine imports, which were a consequence of the general increase in international trade, slowed down as imports encountered the difficulties noted earlier.

\section{Concluding remarks}

In this paper we have tried to highlight how the increase in international trade that took place from the middle of the $19^{\text {th }}$ century until the onset of the economic crisis in 1929 translated into increases in the trade in primary products that differed very considerably from product to product. Thus, if we compare the period 1909-13 with that of 1928-32, we may note that whilst the total trade in these type of products grew in volume by some 38.9 per cent, the trade in wine increased by only 20.2 per cent, whilst trade in fruit achieved an increase of no less than 79.7 per cent. Perhaps even more significantly, the trade in fruits during the period 1928-32/1934-38 actually grew by a significant 4.8 per cent (Aparicio, 2000), despite the fall in the total trade in foodstuffs and agricultural products such as wine from 1929 onwards., During the second half of the nineteenth century, the trend followed by both products had been similarly diverse. On the one hand, there was a dramatic increase in the trade in wine, above all as a consequence of the demand coming from France during the phylloxera outbreak, only for this to fall sharply in the last decade of that century (Pinilla and Ayuda, 2002). By contrast, the trade in fruit enjoyed a sustained pattern of growth throughout this period.

We have tried to demonstrate that such diverse trends were decisively influenced by the response of consumption to the rise in income that took place in the more developed countries. Clearly, the evolution of trade was not conditioned 
solely by the evolution of consumption. This evolution opened a broad range of possibilities, with trade policies, the increase in international competition and the response of the different suppliers determining the final position of the producer countries in the different markets.

In this regard, we have concentrated on analysing variations in the size of the shifts in the demand curve and the reasons which lay behind them. We have found that such shifts were especially conditioned by the different income elasticities of demand and by changes, or otherwise, in consumer preferences. As a consequence, whilst the evolution of consumption, in some cases generated by profound changes in diet, was particularly varied in nature, in the cases of fresh fruit and vegetables, where this demand was high, it offered important opportunities to which the supply side had to offer a response. The lengthy period during which consumption enjoyed sustained growth has been illustrated with the estimations of the demand function for oranges in the United Kingdom, in this way highlighting the importance of the evolution of income in that growth.

By contrast, the case of wine has clearly shown that the possibilities which had been opened up were not in fact exploited, which was a consequence of the limited changes in traditional consumption patterns for alcoholic drinks. The fact that, despite the increase in income in the countries forming the nucleus of European industrialisation, there was no increase in the demand for wine beyond the countries lying on the northern shore of the Mediterranean, or in those that had received significant immigrant flows from that source, meant that the potential opportunities were not in practice developed. These opportunities have been examined in detail for the case of France, where the increase in income was indeed translated into an increase in demand, albeit with a considerably lower elasticity.

Although in this paper we have not considered other alternative factors, it is our view that the consumption of the products analysed here could also have been influenced by the attitude taken to them by the science of Medicine and by modern dietetics, particularly since the beginning of the twentieth century ${ }^{14}$. In the

\footnotetext{
${ }^{14}$ See for more recent times, a quantitative analysis of food demand including these types of variables in Nayga et al. (1999).
} 
case of fruits, the widespread view in favour of an increase in their consumption taken by experts in these fields in the developed countries could have acted in their favour. Wine, by contrast, came up against precisely the opposite situation, because of the limitations on consumption recommended by the healthcare community and the temperance movements, which were particularly relevant in the English-speaking countries.

As a result, whilst the growth in production and exports of Mediterranean horticultural products was important for the development of the Spanish exporting regions, and made a significant contribution to their economic development, the role played by the increase in the production and export of wine was much more episodic and based on prevailing circumstances, being concentrated essentially in the years in which the phylloxera outbreak devastated the French sector. A different trade policy on the part of France might have meant a greater increase in Spanish exports, but this would have done no more than highlight the point to which Spanish exports depended on the consumption of those countries whose populations had traditionally consumed this drink.

\section{ACKNOWLEDGEMENTS}

We are particularly indebted to Antonio Aznar, Domingo Gallego, Peter H. Lindert, Alan L. Olmstead and the Institute for Governmental Affairs of the University of California, Davis. Previous versions have been read and commented on by the participants at the Economic History Seminar at the University of Zaragoza (1997 and 2003), the $6^{\text {th }}$ Spanish Economic History Congress (1997) and the $5^{\text {th }}$ European Historical Economics Society meeting (2003), as well as by Chris Lloyd, Jacob Metzer and Cormac O'Grada. The final version has also benefited from the helpful comments and observations of the Editor and an anonymous referee, to whom the authors extends his thanks. We have relied upon finance from the Spanish Department of Education, Projects PB 98-1596 and PB 98-1579 and the Spanish Department of Science and Technology, Project BEC 2002-03789.

APPENDIX: Data explanations and sources 
A) Table 2. Oranges consumption function: United Kingdom (1854-1935).

GDP: GDP at constant prices (1900 prices), Mitchell (1988).

Orange imports: Statistical Abstract. Until 1892 the statistics drew no distinction between the amounts of oranges and of lemons that were imported. We have estimated the amounts of oranges assuming that the volume of orange imports within the total of orange and lemon imports represented a percentage similar to the arithmetic mean of the years 1893-99.

Price of oranges: Statistical Abstract. Given that up to 1892 we only have the import prices for the totality of oranges and lemons taken together, we have assumed that the relationship between this price and that of oranges individually was the same as that which existed in 1906, the only year for which we have data. Deflated by the United Kingdom consumer price index, Mitchell (1992).

Price of raisins: Statistical Abstract. Deflated by the United Kingdom consumer price index, Mitchell (1992).

Population: Mitchell (1988). Excluding the population of Ireland from 1924 onwards.

B) Table 4. Wine consumption function: France (1860-1938).

GDP: GDP at constant prices (1905-13 prices), Mitchell (1992).

Wine consumption: Annuaire Statistique de la France, p. 177*.

Price of Wine: ibid., p. 62, deflated by the French wholesale price index, Mitchell (1992).

Population: Mitchell (1992).

\section{References}

Annuaire Statistique de la France (1860-1938), Paris.

Aparicio, G. (2002) El Comercio Internacional de Productos Agrarios, 19001940, (unpub. Ph. D. thesis, Univ. of Zaragoza).

Bennett, M.K.(1957) The World's Food, Harper \& Brothers, New York. 
Blaylock, J.R. and Blisard, W.N. (1993) Wine Consumption by U.S. Men, Applied Economics, 25, 5, pp. 645-651.

Briggs, A.(1985) Wine for Sale. Victoria Wine and the Liquor Trade, 1860-198, B.T. Batsford Ltd, London..

Burnett, J. (1989) Plenty and Want. A Social History of Food in England From 1815 to the Present Day, Routledge, London.

Clark, C.(1957) The Conditions of Economic Progress, Macmillan, London.

Clark, G.; Huberman, M. and Lindert, P.H. (1995) A British food puzzle, 17701850, Economic History Review, XLVIII, 2, pp. 215-237.

Commonwealth Economic Committee (1957). Fruit : A Review, London.

Chaudhri, R. and Timmer, C.P.(1986) The impact of changing affluence on diet and demand patterns for agricultural commodities, World Bank Staff Working Papers, 785.

Department of Commerce and Labor Bureau of Statistics (1904) Foreign markets for American Fruits. Washington.

Dickey, D.A. and Fuller, W.A (1981) Likelihood ratio statistics for autoregressive time series with a unit root, Econometrica, 49, 1057-72.

Dickey, D.A. and Fuller, W.A. (1979) Distribution of the Estimators for Autoregressive Time Series with a Unit Root', Journal of the American Statistical Association, 74, 427-31.

Duffy, M. (1983) The Demand for Alcoholic Drink in the United Kingdom, 196378, Applied Economics, 15, 2, pp. 125-140.

Engle, R.F. and Granger, C.W.J. (1987) Cointegration and error correction: representation, estimation and testing, Econometrica, 55, 2, 251-76.

FAO (1948). Commodity Series. Vegetables and Fruits, No. 1., Washington.

Faugeras, J. (1931) Oranges, Citrons, Pamplemousses. Leur Culture et leur Commerce en Floride et en Californie. Paris.

Federico, G. (1992) El comercio exterior de los países mediterráneos en el siglo XIX in El desarrollo económico en la Europa del Sur: España e Italia en perspectiva histórica (Ed.) L. Prados de la Escosura and V. Zamagni, Alianza Editorial, Madrid, pp. 269-92.

Fox, K.A. (1953) The analysis of demand for farm products, Technical Bulletin United States Department of Agriculture, 1081, 1-90.

Hollingshead, S. R, and Wakefield, R. P. (1929) Handbook of Foreign Tariffs and Import Regulations on Agricultural Products, I. Fresh Fruits and Vegetables. Washginton.

Johansen, S. (1991) Estimation and hypothesis testing of cointegration vectors in gaussian vector autoregressive models, Econometrica, 59, 1551-80.

Liniger, M. (1962) L'orange d'Espagne sur les Marchés Européens, Les Editions du Temps, Genève.

Mitchel, B.R. (1988) British Historical Statistics, Cambridge University Press, Cambridge, 
Mitchel, B.R.( 1992) International Historical Statistics. Europe, 1750-1988, Stockton Press, New York.

Moriarty, D. J.( 1930) Foreign Trade in Fresh Fruits. Washington.

Morilla, J, Olmstead, A. L. and Rhode, P.W. (1995) "Horn of plenty": The globalization of mediterranean horticulture and the economic development of southern europe, 1880-1930, Journal of Economic History, 59, 2, 316-52.

Nayga, R.M.; Tepper, B.J. and Rosenzweig, L. (1999) Assesing the importance of Health and Nutrition Related Factors on Food Demand: A Variable Preference Investigation, Applied Economics, 31, 12, pp. 1541-1549.

Nelson, M. (1993) Social-class trends in british diet, 1860-1980', in Food, Diet, and Economic Change Past and Present (Ed.) C. Geissler and D.J. Oddy, Leicester University Press, Leicester, pp. 101-120.

Neumark, S.D. (1938) The Citrus Industry of South Africa, Witwatersrand University Press Johannesburg.

Nye, J.V. (1991) The myth of free-trade britain and fortress france: tariffs and trade in the nineteenth century, The Journal of Economic History, 51, 23-46.

O'Rourke, K.H. and Williamson, J. G. (2002) When did globalisation begin?, European Review of Economic History, 6, part 1, 23-50.

Oddy, D. (1976)A Nutritional Analysis of Historical Evidence: the Working-Class Diet, 1880-191', in The making of the Modern British Diet (Ed.) D. Oddy and D. Miller, Croomhelm, London pp. 215-31.

Offer, A., (1991) The First World War: an agrarian interpretation, Clarendon Press, Oxford.

Ojala, E. M. (1952) Agriculture and Economic Progress, Oxford University Press, London.

Pan-Montojo, J. (1994) LaBodega del Mundo. La Vid y el Vino en España (18001936), Alianza Editorial, Madrid.

Pinilla V. and Ayuda, M.I. (2002) The political economy of the wine trade: spanish exports and the international market, 1890-1935, European Review of Economic History, 6, part.1, 51-86.

Prest, A.R. (1954) Consumer's Expenditure in the United Kingdom, 1900-1919, Cambridge University Press, Cambridge.

Ramon-Muñoz, R. (2000) Specialization in the international market for olive oil before World War II'. In The Mediterranean Response to Globalization Before 1950 (Ed.) S. Pamuk, and J. G. Williamson, Routledge, London, pp. 159-198.

Ritter, K. and Guttfeld, M. (1923) World production of and world trade in table grapes, Monthly Bulletin of Agricultural Economics and Sociology, 9, 285-299.

Schultz, T.W.( 1953) The Economic Organization of Agriculture, Mac Graw Hill, New York. 
Selvanathan , E.A. and Selvanathan, S. (2004) Economic and Demographic Factors in Australian Alcohol Demand, Applied Economics, 36, 21, pp. 2405-2017.

Simpson, J. (1995) Spanish Agriculture: The Long Siesta, 1765-1965, Cambridge.

Simpson, J. (2004) Selling to reluctant drinkers: the British wine market, 18601914, Economic History Review LVII, 1, 80-108.

Sournia, J. (1990) A History of Alcoholism, Basil Blackwell,Oxford.

Statistical Abstract for the United Kingdom (1846-1935), London.

Stone, R. (1954) The Measurement of Consumer's Expenditure and Behaviour in the United Kingdom, 1920-1938, vol. I, Cambridge University Press, Cambridge.

Yates, P. L.(1960) Food, Land and Manpower in Western Europe, Macmillan, London. 


\section{TABLES}

Table 1. Main British horticultural Mediterranean and Wine Imports, 1860-1934

Almonds Grapes Raisins Oranges Tomatoes Onions Wine

\begin{tabular}{|c|c|c|c|c|c|c|c|}
\hline \multicolumn{8}{|c|}{ Imports rate of growth (\%) } \\
\hline $1860-900$ & 4.2 & 11.7 & 1.4 & 5.2 & n.a. & 8.2 & 1.1 \\
\hline $1901-34$ & 2.5 & 1.1 & 2.5 & 2.0 & 4.0 & 1.0 & -0.3 \\
\hline \multicolumn{8}{|c|}{ Per capita imports rate of growth (\%) } \\
\hline $1860-900$ & 3.3 & 10.7 & 0.5 & 4.3 & n.a. & 7.2 & 0.2 \\
\hline $1901-34$ & 2.2 & 0.7 & 2.2 & 1.6 & 3.6 & 0.7 & -0.6 \\
\hline \multicolumn{8}{|c|}{ Volume of imports , $1900=100$} \\
\hline 1860 & 18 & 1 & 58 & 14 & n.a. & 4 & 64 \\
\hline 1900 & 100 & 100 & 100 & 100 & 100 & 100 & 100 \\
\hline 1934 & 227 & 145 & 229 & 191 & 359 & 141 & 91 \\
\hline \multicolumn{8}{|c|}{ Volume of imports per capita, 1900=100 } \\
\hline 1860 & 26 & 2 & 83 & 20 & n.a. & 6 & 92 \\
\hline 1900 & 100 & 100 & 100 & 100 & 100 & 100 & 100 \\
\hline 1934 & 202 & 126 & 204 & 170 & 320 & 125 & 81 \\
\hline
\end{tabular}

Notes:

a $1860=$ average $1859-1861 ; 1900=$ average $1899-1901 ; 1934=$ average $1933-1935$. b oranges are between 1860 and 1900 oranges and lemons; 1900-1934 only oranges. c currants not included in raisins.

Sources:

Mitchell, British Historical Statistics (population).

Statistical Abstract, 1859-1935 (trade), 
Table 2. Estimations of the United Kingdom orange consumption function, 18541935

\begin{tabular}{|c|c|}
\hline Short-run & \\
\hline$\Delta \mathrm{PO}_{\mathrm{t}}$ & $0.18[.321]$ \\
\hline$\Delta \mathrm{PR}_{\mathrm{t}}$ & $-0.11[.408]$ \\
\hline$\Delta \mathrm{I}_{\mathrm{t}}$ & $1.38 *[.020]$ \\
\hline $\mathrm{D} 1 \Delta \mathrm{PO}_{\mathrm{t}}$ & $-0.76 * *[.001]$ \\
\hline $\mathrm{D} 1 \Delta \mathrm{I}_{\mathrm{t}}$ & $1.42[.153]$ \\
\hline $\mathrm{D} 2 \Delta \mathrm{I}_{\mathrm{t}}$ & $-2.10 *[.019]$ \\
\hline$\Delta \mathrm{CO}_{\mathrm{t}-1}$ & $-0.28 *[.017]$ \\
\hline$\Delta \mathrm{PO}_{\mathrm{t}-1}$ & $-0.25[.066]$ \\
\hline $\mathrm{ECM}$ & $-0.68 * *[.000]$ \\
\hline Long-run & \\
\hline 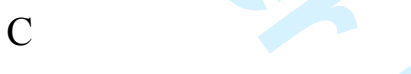 & $-9.42 * *[.000]$ \\
\hline $\mathrm{D} 1_{\mathrm{t}-1}$ & $13.87 *[.010]$ \\
\hline $\mathrm{D} 2_{\mathrm{t}-1}$ & $7.41 * *[.001]$ \\
\hline $\mathrm{PO}_{\mathrm{t}-1}$ & $0.71 * *[.000]$ \\
\hline $\mathrm{PR}_{\mathrm{t}-1}$ & $0.15[.367]$ \\
\hline $\mathrm{I}_{\mathrm{t}-1}$ & $3.05 * *[.000]$ \\
\hline $\mathrm{D} 1 \mathrm{I}_{\mathrm{t}-1}$ & $-2.94 * *[.008]$ \\
\hline $\mathrm{D} 2 \mathrm{I}_{\mathrm{t}-1}$ & $-1.61 * *[.001]$ \\
\hline $\mathrm{R}^{2}=0.98$ & $\mathrm{AIC}=-1.34$ \\
\hline $\bar{R}^{2}=0.97$ & $\mathrm{SBIC}=-0.83$ \\
\hline \multicolumn{2}{|l|}{$R_{\Delta}^{2}=0.66$} \\
\hline \multicolumn{2}{|l|}{$\bar{R}_{\Delta}^{2}=0.57$} \\
\hline LM het. $=75.81[0.356]$ & \\
\hline
\end{tabular}


$\mathrm{D}-\mathrm{W}=2.21$

$\operatorname{LM}(2)=4.16[0.124]$

Note: Values in square brackets are the p-values. $\mathrm{R}^{2}$ is given for levels and differences (denoted by $\Delta$ ). $\mathrm{D}-\mathrm{W}=$ Durbin-Watson test. $\mathrm{LM}$ het. is the White statistic to test homoskedasticity and $\operatorname{LM}(2)$ is the Breusch-Godfrey statistic to test no autocorrelation against autocorrelation of order $2 . *$ means significant at the $5 \%$ level and $* *$ means significant at the $1 \%$ level. $\Delta$ means first differences. $\mathrm{D} 1 \Delta \mathrm{P}_{\mathrm{t}}$ is a variable formed as the product of $\mathrm{D}_{\mathrm{t}}$ and $\Delta \mathrm{P}_{\mathrm{t}}$. It consists of the value of $\Delta \mathrm{P}_{\mathrm{t}}$ for each observation in the war years. $\mathrm{D} 2 \Delta \mathrm{I}_{\mathrm{t}}$ is a variable formed as the product of $\mathrm{D} 2_{\mathrm{t}}$ and $\Delta \mathrm{I}_{\mathrm{t}}$, and consists of the value of $\Delta \mathrm{I}_{\mathrm{t}}$ for each observation from 1898 to 1935 . The rest of the product dummies $\left(\mathrm{D} 1 \Delta \mathrm{I}_{\mathrm{t}}, \mathrm{D} 1 \mathrm{P}_{\mathrm{t}-1} \ldots\right)$ are formed in a similar fashion.

Table 3. Evolution of wine consumption, 1886-1929 (litres per head)

$\begin{array}{rrrrrrrrrrrrrrr} & \text { UK } & \text { DK } & \text { N } & \text { A } & \text { H } & \text { CH } & \text { D } & \text { NL } & \text { B } & \text { F } & \text { P } & \text { E } & \text { I } & \text { USA } \\ 1886-90 & 1.7 & \text { n.a. } & 0.8 & 24.0 & 19.0 & \text { n.a. } & 5.8 & 2.0 & 3.3 & 91.0 & \text { n.a. } 72.0 & 99.0 & 2.0 \\ 1891-95 & 1.7 & \text { n.a. } & 1.2 & 17.0 & 10.0 & \text { n.a. } & 5.4 & 1.9 & 3.8 & 108.0 & \text { n.a. } 85.0 & 91.0 & 1.5 \\ 1896-00 & 1.8 & 1.8 & 2.5 & 18.0 & 11.0 & 75.0 & 6.3 & 1.8 & 4.2 & 130.0 & 92.0 & 87.0 & 92.0 & 1.4 \\ 1901-05 & 1.5 & 1.6 & 1.5 & 18.0 & 18.0 & 75.0 & 7.0 & 1.7 & 4.6 & 139.0 & 92.0 & 88.0 & 112.0 & 1.8 \\ 1906-10 & 1.2 & 1.5 & 1.1 & 19.0 & 22.0 & 55.0 & 4.9 & 1.5 & 5.1 & 144.0 & \text { n.a. } 77.0 & 128.0 & 2.3 \\ 1911-13 & 1.1 & 1.4 & 1.5 & 18.0 & 13.0 & 57.0 & 4.7 & 1.3 & 4.2 & 142.0 & \text { n.a. } 92.0 & 128.0 & 2.3 \\ 1920-24 & 1.3 & 1.6 & 2.7 & 17.0 & 36.0 & 50.0 & 4.5 & 1.5 & 7.7 & 168.0 & \text { n.a. } 96.0 & 92.0 & 0.5 \\ 1925-29 & 1.5 & 1.6 & 2.5 & 15.0 & 22.0 & 44.0 & \text { n.a. } & 1.7 & 6.0 & 160.0 & \text { n.a. } 88.0 & 97.0 & \text { n.a. }\end{array}$

Source: Annuaire Statistique de la France UK= United Kingdom, DK= Denmark, $\mathrm{A}=$ Austria, $\mathrm{N}=$ Norway, $\mathrm{H}=$ Hungary, $\mathrm{CH}=$ Switzerland, $\mathrm{D}=$ Germany, $\mathrm{NL}=$ Netherlands, $\mathrm{B}=$ Belgium, $\mathrm{F}=$ France, $\mathrm{P}=$ Portugal, $\mathrm{E}=$ Spain, $\mathrm{I}=\mathrm{Italy}, \mathrm{USA}=$ United States. 
Table 4. Estimations of the French wine consumption function, 1860-1938

Short-run

\begin{tabular}{ll}
\hline $\mathrm{C}$ & $-0.39[.161]$ \\
\hline$\Delta \mathrm{P}_{\mathrm{t}}$ & $0.01[.651]$ \\
$\Delta \mathrm{I}_{\mathrm{t}}$ & $0.33^{*}[.011]$ \\
$\mathrm{ECM}$ & $-0.68^{* *}[.000]$ \\
\hline Long-run & \\
\hline $\mathrm{D}_{\mathrm{t}-1}$ & $4.39^{* *}[.001]$ \\
$\mathrm{P}_{\mathrm{t}-1}$ & $-0.33^{* *}[.000]$ \\
$\mathrm{I}_{\mathrm{t}-1}$ & $0.91^{* *}[.000]$ \\
$\mathrm{DP}$ & $0.12[.122]$ \\
$\mathrm{DI} \mathrm{t}_{\mathrm{t}-1}$ & $-0.69 * *[.000]$ \\
& \\
$R^{2}=0.87$ & \\
$\bar{R}^{2}=0.86$ & $\mathrm{AIC}=-107.058$ \\
$R_{\Delta}^{2}=0.65$ & $\mathrm{SBIC}=-96.8763$ \\
$\bar{R}_{\Delta}^{2}=0.60$ & \\
$L M h e t .=4.57 *[0.034]$ & \\
$D-W=1.82[<.603]$ & \\
\hline & \\
\hline & \\
\hline
\end{tabular}

Note: Values in square brackets are the p-values. $\mathrm{R}^{2}$ is given for levels and differences (denoted by $\Delta$ ). $\mathrm{D}-\mathrm{W}=$ Durbin-Watson test. * means significant at the $5 \%$ level and $* *$ means significant at the $1 \%$ level. $\Delta$ means first differences. $\mathrm{DP}_{\mathrm{t}-1}$ is a variable formed as the product of $\mathrm{D}_{t}$ and $\mathrm{P}_{\mathrm{t}-1}$, and consists of the value of $\mathrm{P}_{\mathrm{t}-1}$ for each 
observation after the war. The other dummy variable, $\mathrm{DI}_{\mathrm{t}-1}$, is formed in a similar fashion.

\section{FIGURES}

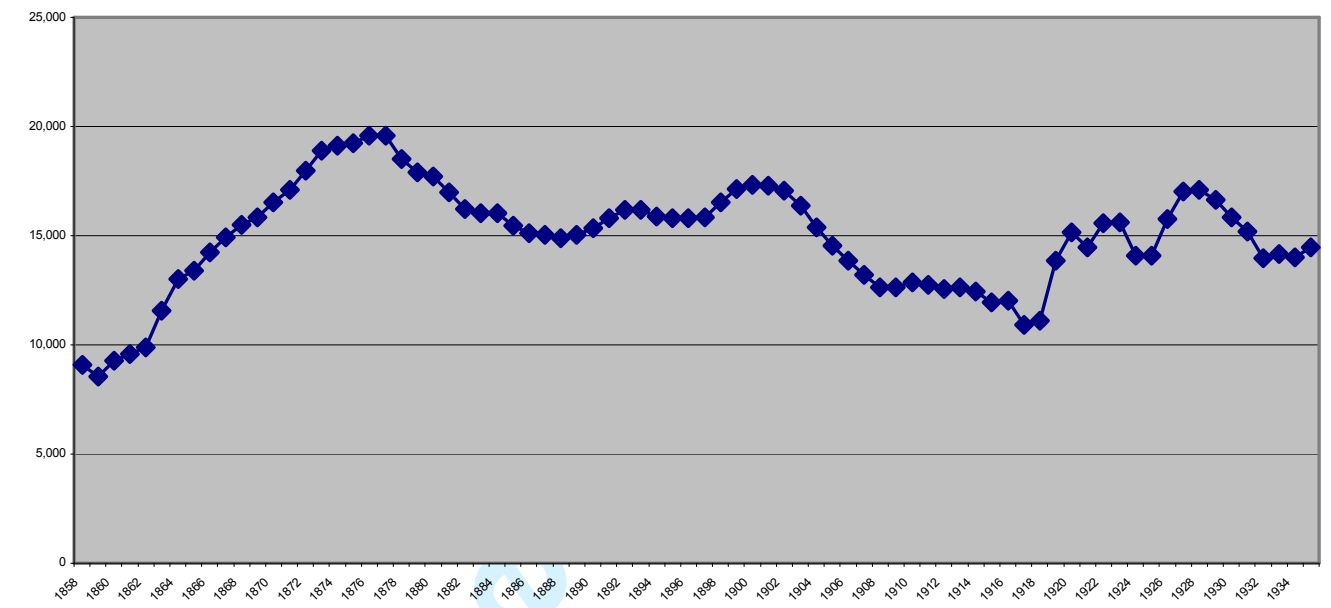

Figure 1. United Kingdom imports of wine, 1854-1935 (thousands of gallons, five year averages)

Source: Statistical Abstract. 